Fall 2013

\title{
The Normative Legitimacy of International Courts
}

Nienke Grossman

University of Baltimore School of Law, ngrossman@ubalt.edu

Follow this and additional works at: http://scholarworks.law.ubalt.edu/all_fac

Part of the Courts Commons, and the International Law Commons

\section{Recommended Citation}

The Normative Legitimacy of International Courts, 86 Temp. L. Rev. 61 (2013)

This Article is brought to you for free and open access by the Faculty Scholarship at ScholarWorks@University of Baltimore School of Law. It has been accepted for inclusion in All Faculty Scholarship by an authorized administrator of ScholarWorks@University of Baltimore School of Law. For more information, please contact snolan@ubalt.edu. 


\title{
THE NORMATIVE LEGITIMACY OF INTERNATIONAL COURTS
}

\author{
Nienke Grossman*
}

This Article's objective is to spark discussion about the standards by which we judge international courts. Traditional justifications for the authority of international courts are based on outmoded assumptions of their role and impact. State consent and procedural fairness to litigants are insufficient to ground the legitimacy of institutions that may adjudicate the international rights and duties of nonlitigants, deeply affect the interests of nonlitigating stakeholders, and shape the law prospectively. These realities mandate a new approach to the legitimacy of international courts. This Article presents alternative or additional approaches for justifying the authority of international courts rooted in both procedure and substance. First, legitimacy requires a reimagining of procedural fairness to include those whose international rights and duties are being adjudicated by international courts. Democratic theory can help to justify the authority of international courts so long as stakeholders are given the opportunity to participate in the formulation of policies that affect them. In addition, international courts must adhere to certain universal standards of justice. They cannot facilitate the violation of a set of core norms, including prohibitions against torture, slavery, racial discrimination, and genocide, and still retain their legitimacy. Finally, the extent to which an international court implements the objectives it was created for also affects its legitimacy.

\section{TABLE OF CONTENTS}

I. INTRODUCTION

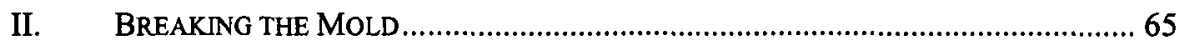

A. The Mold: State Consent and Procedural Fairness To the Litigants......... 65

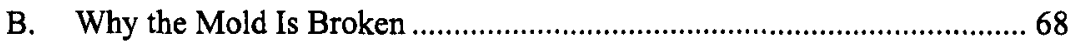

1. Changes in the Role and Impact of International Courts ...................68

\footnotetext{
* Assistant Professor, University of Baltimore School of Law. BA, Harvard College; JD, Harvard Law School; LLM, Georgetown University Law Center. The author wishes to thank for their excellent comments Harlan Grant Cohen, Evan Criddle, Claudio Grossman, Alexandra Huneeus, Harold Hongjuh Koh, Christopher J. Peters, Mortimer Sellers, John Tasioulas, and Markus Wagner, and Ezequiel Steiner for his support throughout this project. In addition, the author benefitted greatly from feedback received at the University of Baltimore School of Law's Junior Faculty Forum, the 2012 Junior International Law Scholars Association meeting, the 2012 ASIL-ESIL-Rechtskulturen Workshop on Transatlantic Debates in International Legal Theory at the University of Cambridge, UK, the 2012 ASIL Research Forum at the University of Georgia, and the 2013 Harvard-Stanford-Yale Junior Faculty Forum. She is grateful to Emily Rogers, Jeffrey Sadri, George Dane Weber, and Amanda Webster for their research assistance, as well as for the University of Baltimore School of Law's summer research grant.
} 


\section{Why These Changes Render Traditional Approaches}

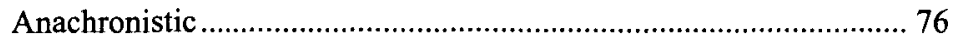

III. A NEW APPROACH TO NORMATIVE LEGITIMACY ............................................ 79

A. Reimagining Procedural Fairness ....................................................... 81

1. Right To a Hearing in Dispute Resolution Proceedings..................... 81

a. International versus domestic courts and the right to a hearing................................................................................ 81

b. The right to a hearing for individuals ..................................... 82

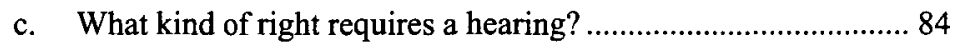

d. What kind of hearing is required? ............................................ 86

e. What if a conflict arises? ......................................................... 86

2. Stakeholder Participation in Judicial Law or Policy Making.............87 87

a. Participation in the conduct of public affairs ................................ 88

b. International courts and the conduct of public affairs ................... 90

c. Who gets to participate and can enhanced participation be antidemocratic? ..................................................................... 92

d. What does participation in the conduct of public affairs

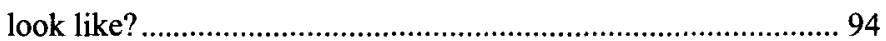

B. What About Justice (or Substantive Legitimacy)? .................................96

1. A Minimum Core Set of Human Rights ........................................ 97

2. Linking the Core Rights to Legitimacy and Counterarguments........100

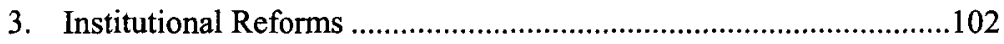

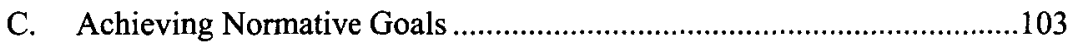

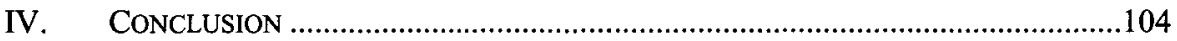

\section{INTRODUCTION}

International courts and tribunals are deciding more disputes involving sovereign states than ever before. They find facts, identify and interpret relevant rules, fill gaps and ambiguities in the law, and apply rules to facts. International court judges are of diverse citizenship, and they are charged with discerning the international responsibility of sovereigns and awarding remedies as mandated by international law. They include the International Court of Justice (ICJ), the World Trade Organization's (WTO) Dispute Settlement Body, ad hoc tribunals under the auspices of the International Centre for the Settlement of Investment Disputes (ICSID), the European Court of Human Rights (ECHR), and many others. ${ }^{1}$ The implications of their decisions, however, often go far beyond determining the rights and responsibilities of the litigating parties in a particular case. They decide who has the right to exploit natural resources and under what conditions, define the scope of our human rights, delimit international boundaries, and determine when the use of force is prohibited.

1. This Article focuses on international adjudicative bodies where at least one of the litigants is a sovereign. Consequently, it does not include international criminal courts, where sovereigns are not litigants. Although they too are international courts, they are involved in the determination of individual rather than state responsibility. 
International courts no longer merely decide one-time disputes before them. They shape and promote specific normative regimes like international investment, human rights, humanitarian law, and trade law. Although international court decisions are not formally binding, advocates before them, scholars, politicians, and judicial opinions frequently cite them as if stare decisis were the prevailing rule. Even if one rejects the value of international court decisions as binding precedent, it is difficult to deny the influence of prior opinions in framing future ones. ${ }^{2}$ Political actors invoke international court opinions as if they constitute law, even when merely advisory. ${ }^{3}$ Judgments can provide a focal point around which interested parties like nongovernmental organizations (NGOs), other states, and domestic and transnational constituencies can mobilize. ${ }^{4}$ Even for states not involved in a particular legal dispute, international court decisions shape the standards by which their behavior is judged prospectively.

Unsurprisingly, as international courts' numbers and influence grow, so too do challenges to their legitimacy. For example, with the burgeoning number of international investment law arbitrations, legitimacy critiques are abundant. ${ }^{5}$ Similarly, the WTO literature is rife with concerns about institutional legitimacy. ${ }^{6}$ We may be seeing renewed attention to the ICJ because of its growing caseload and perceptions of its great influence on international law. By failing to understand and respond to legitimacy concerns, we endanger both the courts and the law they interpret and apply. If international courts lack justified authority, so too will their interpretations of international law. To the extent we want international courts to continue to serve as a forum for the resolution of disputes involving sovereigns, we must preserve their legitimacy. Because no world legislature exists to counterbalance the decisions of international courts, and no worldwide police force enforces them, international courts' legitimacy is all the more essential to their success.

This Article's goals are twofold. First, it seeks to break the mold of previous theories of normative legitimacy of international courts. The Article focuses on normative legitimacy for two reasons. Normative legitimacy provides a standard by

2. See Marc Jacob, Precedents: Lawmaking Through International Adjudication, 12 GERMAN L.J. 1005, 1015 (2011) (addressing both the restrictive and guiding properties of precedent on future opinions); Joel P. Trachtman \& Philip M. Moremen, Costs and Benefits of Private Participation in WTO Dispute Settlement: Whose Right Is It Anyway?, 44 HARV. INT'L L.J. 221, 223 (2003) (noting that even though stare decisis does not apply in WTO litigation, judicial opinions often have some legislative force, filling in gaps left open by treaty writers and legislators); Armin von Bogdandy \& Ingo Venzke, In Whose Name? An Investigation of International Courts' Public Authority and Its Democratic Justification, 23 EUR. J. INT'L L. 7, 18 (2012) (stating that some international courts have certain coercive mechanisms that require adherence to precedent in future decisions).

3. See infra notes 37-41 and accompanying text for examples.

4. KAREN Alter, THE NEW TerRain OF INTERNATIONAL LAW (forthcoming 2013) (manuscript at 1617).

5. See, e.g., David D. Caron, Investor State Arbitration: Strategic and Tactical Perspectives on Legitimacy, 32 SUFFOLK TRANSNAT'L L. REV. 513, 515-16 (2009) (noting multiple legitimacy critiques of the system of investor state arbitration); Bruno Simma, Foreign Investment Arbitration: A Place for Human Rights?, 60 INT'L \& COMP. L.Q. 573, 573 (2011) (stating that the legitimacy of international investment treaties and arbitration has been attacked in recent years).

6. See, e.g., Jeffery Atik, Democratizing the WTO, 33 Geo. WASH. INT'L L. REV. 451, 452-53 (2001) (asserting that public interest groups, public intellectuals, and trade scholars have all "underscored the WTO's legitimacy problem"). 
which to judge an international court and to decide whether it merits support. ${ }^{7}$ It seeks to identify what qualities provide international courts with the "right to rule" or what justifies their authority. ${ }^{8}$ It is objective and rooted in philosophy or political theory. ${ }^{9}$ In addition, normative legitimacy can influence sociological legitimacy, or perceptions of justified authority, and thereby, the extent to which we undergird or undercut the work of international courts. ${ }^{10}$ If international actors perceive an international court as illegitimate, they can defund the court, ignore its decisions, or render its rulings irrelevant. While legitimacy is not the only normative standard by which international courts can be judged, it is a vital one. It tells us why a state should obey a court's ruling even if it may run contrary to the state's perceived interests to do so. It allows for the coordination of support by many different actors because it is based in moral, rather than strategic or self-interested reasons. ${ }^{11}$ Normative legitimacy can help identify where international courts are lacking and what can be done to strengthen them.

As Section II explains, traditional approaches to normative legitimacy are based on outmoded assumptions about the effects of international court decisions beyond the litigating parties and the purposes of international adjudication. The beneficiaries of international court decisions include a multitude of actors not immediately before a court in a particular case, such as states, individuals, peoples, and corporations. International adjudication's underlying goals have changed dramatically since the late nineteenth and early twentieth centuries from an almost exclusive focus on state-tostate dispute settlement to prevent war to something much more complex. The objectives of international adjudicative bodies today include the advancement of particular normative goals like the promotion of human rights or trade and the maintenance of cooperative arrangements. ${ }^{12} \mathrm{We}$ must acknowledge these realities and their implications. The predominant approaches to normative legitimacy are anachronistic.

The second objective of this Article, in Section III, is to propose a new theory of

7. See Allen Buchanan \& Robert O. Keohane, The Legitimacy of Global Governance Institutions, 20.4 ETHICS \& INT'L AFFAIRS 405, 405-06 (2006) (suggesting that a global public standard of legitimacy can help citizens distinguish legitimate institutions from illegitimate ones).

8. Id. at 405; Daniel Bodansky, The Legitimacy of International Governance: $A$ Coming Challenge for International Environmental Law?, 93 AM. J. INT'L L. 596, 601 (1999).

9. Daniel Bodansky, The Concept of Legitimacy in International Law, in LEGITIMACY IN INTERNATIONAL LAW 309, 313 (Rudiger Wolfrum \& Volker Röben eds., 2008).

10. See Bodansky, supra note 8, at 601 (asserting that popular views about an authority comprise one dimension of that authority's legitimacy); Buchanan \& Keohane, supra note 7, at 405 ("An institution is legitimate in the sociological sense when it is widely believed to have the right to rule."); Richard H. Fallon Jr., Legitimacy and the Constitution, 118 HARV. L. REV. 1787, 1795 (2005) (discussing legitimacy as a sociological concept and defining it as whether the relevant public views the authority as justified or appropriate). Sociological legitimacy is drawn from the work of Max Weber. MAX WEBER, MAX WEBER ON LAW IN ECONOMY AND SOCIETY 5 (Max Rheinstein ed., Edward Shils \& Max Rheinstein trans., Harvard University Press 1969); Nienke Grossman, Legitimacy and International Adjudicative Bodies, 41 GEO. WASH. INT'L L. REV. 107, 116 (2009); Alan Hyde, The Concept of Legitimation in the Sociology of Law, 1983 WIS. L. REV. 379, 380-82 (1983). Sociological legitimacy is subjective, agent relative, and dynamic, and can be tested by empirical research. Grossman, supra, at 116-17; Bodansky, supra note 9, at 313.

11. Buchanan \& Keohane, supra note 7, at 409.

12. Yuval Shany, No Longer a Weak Department of Power? Reflections on the Emergence of a New International Judiciary, 20 EURO. J. INT'L L. 73, 76 (2009). 
normative legitimacy for international courts. Legitimacy is a complex concept, and many different elements contribute to it. Identifying all of them is a Herculean, if not impossible, task. This Article proposes procedural and substantive requirements. First, a theory of legitimacy of international courts must, at a minimum, recognize the role and rights of actors beyond the state and the changed purposes of international adjudication. Specifically, legitimacy requires a reimagining of procedural fairness to include nonlitigants and nonstate parties, whose international rights and duties are being adjudicated by international courts, and stakeholders, when courts are engaged in law or policy making. Further, international courts' legitimacy turns, in part, on their ability to help states do a better job of complying with a core set of human rights obligations than states would in their absence..$^{13}$ Also, international courts cannot facilitate the violation by states of these core norms and retain their legitimacy. Finally, legitimacy hinges on how well courts further the underlying purposes of the normative regimes they were established to interpret and apply.

Despite the proliferation of international courts and tribunals, "no new theory accompanies them. We continue to think about international adjudication in view of ideas and proposals dating back to around the turn of the twentieth century."14 The purpose of this Article is to challenge prevailing assumptions about the normative legitimacy of international adjudicative bodies and to begin a discussion about the standards by which they should be judged.

\section{BREAKING THE MOLD}

\section{A. The Mold: State Consent and Procedural Fairness to the Litigants}

State consent is one traditional approach to normative legitimacy. The idea is that international institutions, including international adjudicative bodies, derive legitimacy from the consent of states to their jurisdiction. ${ }^{15}$ The state consent approach legitimates authority by focusing on its sources or origins. ${ }^{16}$ So long as states consent to it, authority is justified. Because states are sovereign and independent, an international

13. See infra Part III.B.2 for this Article's adoption of an instrumentalist approach to legitimacy inspired by Joseph Raz's "service conception" of authority. Raz describes the service conception as a "normative doctrine about the conditions under which authority is legitimate and the manner in which authorities should conduct themselves." JOSEPH RAZ, THE MORALITY OF FREEDOM 63 (1986); see also John Tasioulas, Parochialism and the Legitimacy of International Law, in PAROCHIALISM, COSMOPOLITANISM, AND THE FOUNDATIONS OF INTERNATIONAL LAW 16, 19 (M.N.S. Sellers ed., 2012); Lukas H. Meyer \& Pranay Sanklecha, Introduction, to LEgITIMACY, JUSTICE AND PUBLIC INTERNATIONAL LAW 5-8 (Lukas H. Meyer, ed., 2009).

14. Martti Koskenniemi, The Ideology of International Adjudication and the 1907 Hague Conference, in Topicality of the 1907 Hague Conference, the SeCONd Peace Conference 127, 127 (Yves Daudet ed., 2008); see also Armin von Bogdandy \& Ingo Venzke, Beyond Dispute: International Judicial Institutions as Lawmakers, 12 GERMAN L.J. 979, 980 (2011) (asserting that "neither theory nor doctrine has yet adequately captured" the increase in volume or change in development of international courts).

15. JAN KLABBERS ET AL., THE CONSTITUTIONALIZATION OF INTERNATIONAL LAW 39 (2009); Meyer \& Sanklecha, supra note 13, at 4; Bodansky, supra note 8, at 597, 605; Buchanan \& Keohane, supra note 7, at 412-13.

16. Rüdiger Wolfrum, Legitimacy of International Law from a Legal Perspective: Some Introductory Considerations, in LEGITIMACY IN INTERNATIONAL LAW, supra note 9, at 1, 6. 
adjudicative body cannot justify the exercise of its power to decide disputes involving states without their agreement. In the words of the Permanent Court of International Justice, the predecessor court to the ICJ:

This rule, moreover, only accepts and applies a principle which is a fundamental principle of international law, namely, the principle of the independence of States. It is well established in international law that no State can, without its consent, be compelled to submit its disputes with other States either to mediation or to arbitration, or to any other kind of pacific settlement. $^{17}$

More recently, in Application of the International Convention on the Elimination of All Forms of Racial Discrimination (Georgia v. Russian Federation), ${ }^{18}$ the ICJ stressed the importance of the "fundamental principle of consent."19

In the same vein, a court that acts beyond the scope of the authority delegated by states, or ultra vires, lacks legitimacy. ${ }^{20}$ Also called "legality" or "legal legitimacy," it too traces to state consent. ${ }^{21}$ When states submit to the jurisdiction of a court, they do so under a specified set of conditions and expectations of the court's power. These conditions are established in a court's statute or in an arbitration agreement or compromis. For example, states may prescribe the sources of law that a court must rely upon. Article 38 of the Statute of the ICJ contains the canonical list of the sources the court "shall apply."22 Similarly, the Convention on the Settlement of Investment Disputes Between States and Nationals of Other States provides that arbitral tribunals must

decide a dispute in accordance with such rules of law as may be agreed by the parties. In the absence of such agreement, the Tribunal shall apply the law of the Contracting State party to the dispute (including its rules on the conflict of laws) and such rules of international law as may be applicable. ${ }^{23}$

If a court were to apply some other source of law, it would disrespect the boundaries prescribed by state consent, and its authority would lack justification. Again, the key to authority is the consent of states. A court that evades or ignores the limitations placed upon its authority by states threatens its legitimacy.

The frame of reference for analyzing the grant and scope of consent is almost

17. Status of Eastern Carelia, Advisory Opinion, 1923 P.C.I.J. (ser. B) No. 5, ๆ 33 (July 23); see also Armed Activities on Territory of Congo (Dem. Rep. Congo v. Rwanda), Provisional Measures, 2002 I.C.J. 220,220 (finding that litigating states must grant consent for the ICJ to adjudicate their disputes); Monetary Gold Removed from Rome in 1943 (It. v. Fr., U.K., U.S.), Preliminary Question, 1954 I.C.J. 19, 34 (June 15) (noting that the ICJ cannot determine the international responsibility of a state without its consent).

18. Preliminary Objections, 2011 I.C.J. 1 (Apr. 1).

19. Elimination of Racial Discrimination, 2011 I.C.J. ๆ 131.

20. Bodansky, supra note 8 , at 605 .

21. Id. at 605.

22. Statute of the International Court of Justice art. 38, June 26, 1945, 33 U.N.T.S. 993 [hereinafter ICJ Statute]; H. Vern Clemons, Comment, The Ethos of the International Court of Justice Is Dependent upon the Statutory Authority Attributed to Its Rhetoric: A Metadiscourse, 20 FORDHAM INT'L L.J. 1479, 1486-87 (1996).

23. Convention on the Settlement of Investment Disputes Between States and Nationals of Other States art. 42, opened for signature Mar. 18, 1965, 17 U.S.T. 1270, 575 U.N.T.S. 186 [hereinafter ICSID Convention]. 
always the state, and no other entity or person. Courts consider whether a state has consented and analyze the scope of that consent. Even in bodies where nonstate actors may sue states, such as the ECHR and ICSID, jurisdiction still rests on an expression of state consent. ${ }^{24}$

A second traditional approach to legitimacy focuses on the fairness and adequacy of decision-making processes. ${ }^{25}$ While the state consent approach derives legitimacy from the origins of authority, the process approach links the legitimacy of a court to the processes it uses to render decisions. ${ }^{26}$ The idea is that the rulings of a court with fair and impartial adjudicators and processes are worthy of respect, while those from unfair judges and processes are not. An international adjudicative body that operates by rules that ensure fairness and impartiality to the litigating parties is more legitimate than one that is biased against one of the litigating parties or fails to afford them equal opportunities to be heard. ${ }^{27}$

A legitimate process will provide litigants with equal opportunities to present their views both orally and in writing and to respond to the views of the opposing party. Then, an open-minded adjudicator will assess the arguments and produce a judgment that one or both litigants may disagree with, but is authoritative nonetheless. ${ }^{28}$ Procedural fairness is associated with the principle of audi alteram partem, literally,

24. E.g., European Convention for the Protection of Human Rights and Fundamental Freedoms art. 25, Nov. 4, 1950, 213 U.N.T.S. 221 [hereinafter ECHR]; ICSID Convention, supra note 23, art. 25.

25. See Thomas M. FranCK, FaIRnESS IN INTERnational LAW AND InSTITUTIONS 7 (1995) (discussing both procedural and substantive fairness); Bodansky, supra note 8, at 612 (stating that "authority can be legitimate because it involves procedures considered to be fair"); J.H.H. Weiler, The Rule of Lawyers and the Ethos of Diplomats: Reflections on the Internal and External Legitimacy of WTO Dispute Settlement, $35 \mathrm{~J}$. WORLD TRADE 191, 204 (2001) (explaining that the legitimacy of courts is largely based on their ability "to listen to the parties, to deliberate impartially favoring neither the powerful nor the meek, to have the courage to decide and then, crucially, to motivate and explain the decisions").

26. Rudiger Wolfrum identifies source-, procedure-, and result-oriented approaches for legitimating authority. Wolfrum, supra note 16 , at 6 .

27. See Lon L. Fuller, The Forms and Limits of Adjudication, 92 HARV. L. REV. 353, 382 (1978) (arguing that the integrity of adjudication must be judged by whether "the meaning of the affected party's participation in the decision by proofs and reasoned arguments" is adversely affected); Application for Review of Judgment No. 158 of United Nations Administrative Tribunal, Advisory Opinion, 1973 I.C.J. 166, 179 (July 12) ("The principle of equality of the parties follows from the requirements of good administration of justice." (quoting Judgments of Administrative Tribunal of International Labour Organisation upon Complaints Made Against United Nations Educational Scientific and Cultural Organisation, Advisory Opinion, 1956 I.C.J. 77, 86 (Oct. 23))); Martin Shapiro, Courts: A Comparative and Political ANalysis 1 (1981) (discussing the "ideal type" of courts, involving "an independent judge" and "adversary proceedings," among other elements); Application for Review of Judgment No. 158 of United Nations Administrative Tribunal, Advisory Opinion, 1973 I.C.J. 166, 179 (July 12) ("The principle of equality of the parties follows from the requirements of good administration of justice." (quoting Judgments of Administrative Tribunal of International Labour Organisation upon Complaints Made Against United Nations Educational Scientific and Cultural Organisation, Advisory Opinion, 1956 I.C.J. 77, 86 (Oct. 23)); Lon L. Fuller, The Forms and Limits of Adjudication, 92 HARV. L. REV. 353, 382 (1978) (arguing that the integrity of adjudication must be judged by whether "the meaning of the affected party's participation in the decision by proofs and reasoned arguments" is "adversely affected").

28. Martin Shapiro calls this the "triad." SHAPIRO, supra note 27, at 1-2. The further one moves away from the characteristics of the triad, the greater the challenges to a court's legitimacy. Id. 
"[1]isten to the other side." 29 It requires that international courts, like domestic ones, treat all parties equally and provide equal opportunities for advocacy. ${ }^{30}$ In the words of the ICJ, such principles "are integral constituents of the rule of law and justice." 31 Fair process focuses on the litigants before a tribunal in a particular case, not on interested or potentially affected parties beyond the courtroom. The approach assumes, too, that open-minded and impartial adjudicators exist and that we can construct impartial benches.

An alternative approach to the legitimacy of international courts is to apply a justice lens to outcomes. Even if states consent to adjudication and procedures are fair, a court that makes immoral or unjust rulings lacks legitimacy. This approach differs from the consent and process approaches because it focuses on institutional outputs, rather than what engenders them. It assumes that an objective and universal standard of justice exists and is discernible. Because many scholars have shied away from justice in assessing the legitimacy of international courts, it is not included within the "traditional approaches" critiqued below, but rather is addressed in Part III.B.

\section{B. Why the Mold Is Broken}

\section{Changes in the Role and Impact of International Courts}

The traditional approaches to normative legitimacy of international courts rest on at least two flawed assumptions. The first is that international courts affect only the litigants in a particular case. The second is that international courts' primary role is to resolve one-time disputes between state actors. These assumptions are either too simple or just plain wrong. First, the influence of international courts extends far beyond the litigating parties because international courts make law that is used by other courts and nonlitigants. International courts shape the obligations of states prospectively and impact both state and nonstate actors not before the court. Second, rather than solely deciding narrow disputes between states, international courts explicitly promote specific normative regimes like human rights or free trade. These realities have serious implications for traditional approaches to normative legitimacy.

International court decisions influence the development of law and politics. "The de facto lawmaking role played by international judges cannot be denied." 32 Judges, lawyers, scholars, and politicians use previous international court decisions to support their legal arguments and to justify policy decisions. A quick read of almost any international court's opinions shows that judges cite and place weight on their own

29. Aaron X. Fellmeth \& Maurice Horwitz, Guide to Latin in InTERnational LaW 41 (2009).

30. Id.

31. Request for Examination of Situation in Accordance with Paragraph 63 of Court's Judgment of 20 December 1974 in Nuclear Tests Case (N.Z. v. Fr.), 1995 I.C.J. 288, 325 (Sept. 22).

32. Daniel Terris et al., The International Judge: An Introduction to the Men and Women WHO DECIDE THE WORLD'S CASES $115-17$ (2007) (discussing a number of different examples, ranging from the European and Inter-American human rights courts' contribution to the development of human rights law "far beyond what the original drafters [of the respective conventions] might have conceived," to the role of the European Court of Justice in European integration, to the WTO Appellate Body's inclusion of other areas of international law within its jurisdiction); see also von Bogdandy \& Venzke, supra note 14, at 979 (stating that international judicial decisions influence future decisions). 
court's previous decisions. ${ }^{33}$ International judges admit that they examine and consider other courts' decisions when relevant. Former vice president of the ICJ, Judge Guy de Lacharrière stated: "There is a body of international jurisprudence. When a case is presented to an international tribunal, be it our own tribunal or any ad hoc arbitration tribunal, the judge, the members of this tribunal, draw constantly from the international jurisprudence." 34 Former ICJ Judge Thomas Buergenthal acknowledged,

Contrary to what one would think, we at the ICJ do read decisions of other courts that bear on what we are doing. And even though we don't cite them-I've written and said we should cite them, but we don't cite themwe do read them, and we take different views into account when they are relevant. ${ }^{35}$

Further, a number of courts, including the ICJ, have cited the opinions of other courts. The Andean Tribunal of Justice has repeatedly referenced the European Court of Justice's (ECJ) jurisprudence on the preemptive power and supremacy of community law and intellectual property law. ${ }^{36}$ In EC Measures Concerning Meat and Meat Products (Hormones), ${ }^{37}$ the WTO Appellate Body cited the ICJ's judgment in Gabcikovo-Nagymaros Project (Hungary/Slovakia) ${ }^{38}$ on the legal status of the precautionary principle. ${ }^{39}$ The ICJ quoted the International Criminal Tribunal for the former Yugoslavia on the meaning of intent to commit genocide. ${ }^{40}$

Lawyers, too, cite decisions of other courts or previous decisions of the same court in making legal arguments. ${ }^{41}$ Although judicial opinions are supposed to be only

33. See Mohamed Shahabuddeen, Precedent in the World Court 29-31 (1996) ("The cumulative effect of these and other instances is to establish, first, the existence of a case law of the Court, and second, the practical importance which the Court attaches to the maintenance of consistency in its holdings. As to the first point, the Court is itself on record as treating its previous decisions as constituting 'the case-law of the Court'."); von Bogdandy \& Venzke, supra note 14, at 981 (discussing the development of international investment law as judge-made law).

34. Garry Sturgess \& Philip ChubB, Judging the World: LAW and Politics In the World's LEADING COURTS 458 (1988).

35. TERRIS ET AL., supra note 32, at 98.

36. Ricardo Vigil Toledo, El reflejo de la jurisprudencia europea en los fallos del Tribunal

de Justicia de la Comunidad Andina: aspectos teóricos y pragmáticos [European Jurisprudence as Reflected in Judgments of the Court of Justice of the Andean Community: Theoretical and Pragmatic Aspects] 1-4 (Feb. 10, 2011) (unpublished manuscript), available at http://www.upf.edu/constitucional/actualitat/PDFs/abstracts/ Vigil.pdf; see also Karen J. Alter \& Laurence R. Helfer, Nature or Nurture? Judicial Lawmaking in the European Court of Justice and the Andean Tribunal of Justice, 64 INT'L ORG. 563, 570 (2010) (observing that the Andean Tribunal of Justice in its first case declared the supremacy of Andean law by citing a decision of the European Court of Justice that obligated national courts to enforce community law).

37. Appellate Body Report, WT/DS26/AB/R, WT/DS48/AB/R (Jan. 16, 1998).

38. Judgment, 1997 I.C.J. 7 (Sept. 25).

39. Meat Products Report, I 123, WT/DS26/AB/R, WT/DS48/AB/R (citing Gabčikovo-Nagymaros Project (Hung./Slovk.), Judgment, 1997 I.C.J. 7, ๆף 111-114, 140).

40. Application of Convention on Prevention and Punishment of Crime of Genocide (Bosn. \& Herz. v. Serb. \& Montenegro), Judgment, 2007 I.C.J. 43, \188 (Feb. 26).

41. For example, in Questions of Mutual Assistance in Criminal Matter (Djibouti v. France), in the ICJ, counsel for both France and Djibouti cited a number of ICSID arbitral tribunal awards in discussing selfjudging clauses in treaties. E.g., Certain Questions of Mutual Assistance in Criminal Matters (Djib. v. Fr.), 2008 I.C.J. Pleadings 24 (Jan. 29, 2008) (citing CMS Gas Transmission Co. v. Argentine Republic, ICSID Case No. ARB/01/8, Award, I 371 (May 12, 2005)); Certain Questions of Mutual Assistance in Criminal 
a "subsidiary means" for the determination of international law, ${ }^{42}$ academics and renowned publicists rely on international court decisions when restating international legal principles or engaging in the progressive development of international law. For example, the International Law Commission makes reference to the decisions of international adjudicative bodies, especially the ICJ, in drafting international treaties for states' consideration and adoption. ${ }^{43}$ Political bodies like the United Nations General Assembly use even merely advisory opinions to pressure states. The United Nations General Assembly used the ICJ's advisory opinion in Legal Consequences of the Construction of a Wall in the Occupied Palestinian Territory"4 to "demand[]" that Israel comply with the opinion, by a vote of 150 to 6 , even though Israel never consented to the jurisdiction of the court. ${ }^{45}$ Advisory opinions not only shape political conditions but also contribute to the development of international legal principles. ${ }^{46}$ International court opinions, too, can serve as focal points to mobilize domestic and international interest groups in favor of or against a particular policy. ${ }^{47}$

International judicial decisions can either directly or indirectly affect a broad range of stakeholders not immediately before the court, such as other states, peoples, individuals, and corporations. Indeed, some judges admit that international court decisions are intended to have impacts beyond the litigating parties at the time they are written. Former ICJ judge and president, Manfred Lachs, commented that:

[Y]ou do not only decide the dispute between state $A$ and state $B$, you perform an educational function. You indicate to states A and B how their dispute should be solved, but you also give a wider background to all nations so that similar issues, or related issues, should be solved in a similar way. ${ }^{48}$

Lachs advocated the articulation of obiter dicta, or articulated general principles unnecessary to resolve the dispute, to clarify the law and provide guidance to states about their responsibilities to the international community. ${ }^{49}$ Similarly, former president of the ICJ, Nagendra Singh, added that judges "generalise and enunciate

Matters (Djib. v. Fr.), 2008 I.C.J. Pleadings 23 (Jan. 22, 2008) (citing Enron Corp. \& Ponderosa Assets v. Argentine Republic, ICSID Case No. ARB/01/3, Award, 价 322-45 (May 22, 2007); CMS Gas Transmission Co. v. Argentine Republic, ICSID Case No. ARB/01/8, Award, ๆๆ 353-78 (May 12, 2005); Sempra Energy Int'l v. Argentine Republic, ICSID Case No. ARB/02/16, Award, ๆ $364-91$ (Sept. 28, 2007)).

42. ICJ Statute, supra note 22, art. 38.

43. For example, in its Draft Articles on the Law of Treaties with Commentaries, the International Law Commission commented that " $[t]$ here is much authority in the jurisprudence of international tribunals for the proposition that in the present context the principle of good faith is a legal principle which forms an integral part of the rule pacta sunt servanda." INT'L LAW COMM'N, DRAFT ARTICLES ON THE LAW OF TREATIES WITH COMMENTARIES $211 \mathrm{cmt} .2$ (1966). This statement is supported by a discussion of decisions of the ICJ, the Permanent Court of International Justice, and arbitral tribunals. $I d$.

44. Advisory Opinion, 2004 I.C.J. 136 (July 9).

45. G.A. Res. 10/15, at 4, U.N. Doc. A/RES/ES-10/15 (Aug. 2, 2004).

46. See Karin Oellers-Frahm, Lawmaking Through Advisory Opinions?, 12 GERMAN L.J. 1032, 1040-41 (2011).

47. See ALTER, supra note 4, at 16-17 (discussing "politically meaningful" rulings that may elicit state or government responses); Christina Binder, The Prohibition of Amnesties by the Inter-American Court of Human Rights, 12 GERMAN L.J. 1203, 1225-26 (2011) (arguing that the prohibition of amnesty laws by the Inter-American Court helped domestic courts and human rights constituencies fight impunity).

48. STURGESS \& CHUBB, supra note 34 , at 89.

49. Id. at 90 . 
principles of jurisprudence which would serve as a guide to prevent future disputes and to the establishment of a regime of law." 50

Decisions can shape the law prospectively by creating or limiting rights and obligations for nonlitigating states, as well as individuals. For example, the decision of the Inter-American Court of Human Rights in Barrios Altos v. Peru ${ }^{51}$ that all amnesty laws violate the Inter-American Convention on Human Rights, not just the one immediately before the court, impacted all states with such laws that were also parties to the Convention. ${ }^{52}$ It also created the theoretical possibility for legal relief for many individuals whose claims were previously barred by amnesty laws.

In several recent cases in the ICJ, nonlitigants' rights were directly affected by proceedings in which they had no right to appear. For example, Jurisdictional Immunities of the State (Germany v. Italy: Greece Intervening) ${ }^{53}$ had significant impacts on nonlitigating parties. The court ruled that states enjoy jurisdictional immunity for acta jure imperii ${ }^{54}$ occasioning death, personal injury, or damage to property committed by armed forces or other state organs in the forum state during the course of an armed conflict, and that the gravity of the crimes committed or the lack of any other remedy does not warrant a suspension of immunity under customary international law as it currently stands. ${ }^{55}$ As a result, Italian and Greek citizens who suffered from massacres of loved ones, forced labor, or improper denials of prisoner of war status by the German Reich lost their right to a remedy for serious violations of their human rights, ${ }^{56}$ despite that several human rights instruments require states to provide remedies for violations of human rights. ${ }^{57}$ Future claimants will suffer the consequences of this decision too.

Similarly, the ICJ's advisory opinion in an appeal from a decision of the International Labour Organization's Administrative Tribunal dealt directly with the

50. Id. at 452 .

51. Merits, Judgment, Inter-Am. Ct. H.R. (ser. C) No. 75, (Mar. 14, 2001).

52. Barrios Altos, Inter-Am. Ct. H.R. (ser. C) No. 75, ๆ 41 (deeming all “amnesty provisions, provisions on prescription and the establishment of measures designed to eliminate responsibility" as inadmissible); see also Binder, supra note 47, at 1209-11, 1222-26 (discussing subsequent Inter-American Court of Human Rights cases relying upon this decision and the reaction of nonlitigating states).

53. Judgment, 2012 I.C.J. 1 (Feb. 3).

54. Acta jure imperii are acts concerning the exercise of sovereign power. Jurisdictional Immunities, 2012 I.C.J. \ 60.

55. Id. $1177,91,97$.

56. See id. 19104,139 ("In coming to this conclusion, the Court is not unaware that the immunity from jurisdiction of Germany in accordance with international law may preclude judicial redress for the Italian nationals concerned.").

57. See, e.g., Convention against Torture and Other Cruel, Inhuman or Degrading Treatment or Punishment art. 14, adopted Dec. 10, 1984, 108 Stat. 382, 1465 U.N.T.S. 112 (declaring that "[e]ach State Party shall ensure in its legal system that the victim of an act of torture obtains redress"); International Covenant on Civil and Political Rights art. 2, adopted Dec. 19, 1966, 999 U.N.T.S. 171 (requiring each signatory to "adopt such legislative or other measures as may be necessary" to ensure available remedies for violations of human rights); Universal Declaration of Human Rights art. 8, G.A. Res. 217 (III) A, U.N. Doc. A/RES/217(III) (Dec. 10, 1948) (declaring that "[e]veryone has the right to an effective remedy by the competent national tribunals for acts violating the fundamental rights granted him by the constitution or by law"). 
rights of an employee of the International Fund for Agricultural Development. ${ }^{58}$ Although the complainant before the Administrative Tribunal had no right to speak or to representation derived from the ICJ Statute, the ICJ gave her the opportunity to present her views in writing, implicitly recognizing the direct impact of the case on her rights. ${ }^{59}$

The Chevron Corp. \& Texaco Petroleum Co. v. Ecuador ${ }^{60}$ case in the Permanent Court of Arbitration (PCA) is another stark example of how nonlitigants' rights or interests may be directly affected by proceedings in which they may play no part. This case involved a determination of responsibility over environmental degradation and personal injuries that Texaco Petroleum's activities allegedly caused to tens of thousands of Ecuadorians. ${ }^{61}$ After the filing of several lawsuits by both Ecuadorian plaintiffs and Chevron in both the United States and Ecuador, Chevron and Texaco filed a Notice of Arbitration in the PCA in The Hague, the Netherlands, in 2009.62 Specifically, Chevron and Texaco alleged that Ecuador violated several provisions of the Ecuador-United States Bilateral Investment Treaty, including its obligations to (1) provide fair and equitable treatment to the claimants' investment, (2) provide effective means of asserting and enforcing rights under the treaty, (3) not to impair a number of rights with respect to the use of the investment, (4) not to treat the investment less favorably than national investments, and (5) to observe any obligations entered into with respect to the investment. ${ }^{63}$ Chevron asked the court to declare that it had "no liability or responsibility for environmental impact, including but not limited to . . human health, the ecosystem, indigenous cultures, [and] the infrastructure." ${ }^{.64}$ The 1976 Rules of the United Nations Commission on International Trade Law (UNCITRAL) applicable to this dispute did not provide for amicus curiae, or "friend of the court," briefs. ${ }^{65}$ Consequently, if decisions in this case directly affected the rights or interests of indigenous peoples, as Fundación Pachamama and the International Institute for Sustainable Development argued in a brief to the $\mathrm{PCA},{ }^{66}$ the rules provided no right for

58. Judgment No. 2867 of the Administrative Tribunal of the Intemational Labour Organization upon Complaint Filed Against the International Fund for Agricultural Development, Advisory Opinion, 2012 I.C.J. 1 (Feb. 1).

59. Id. ๆ 3 .

60. Case No. 2009-23 (Perm. Ct. Arb. 2009).

61. Claimants' Notice of Arbitration $\uparrow 25$, Chevron Corp. \& Texaco Petroleum Co. v. Ecuador, Case No. 2009-23 (Perm. Ct. Arb. 2009). In November 1993, a class of 30,000 Ecuadorian plaintiffs sued Texaco, Inc., in federal court in the Southern District of New York, for personal injury and damage to their property caused by petroleum operations in Ecuador. Id. In May 2003, another set of plaintiffs sued Chevron in Lago Agrio, Ecuador, after the 1993 U.S. suit was dismissed for forum non conveniens. Id. १ๆ 25,30 .

62. Id. 9725,30 .

63. Id. ๆ 69.

64. Id. $ๆ 76$.

65. Id. at 1 (stating that the notice was "proceeding under the UNCITRAL Arbitration Rules"); United Nations Commission on International Trade Law Arbitration Rules, G.A. Res. 31/98, U.N. Doc. A/RES/31/98 (Dec. 15, 1976) (lacking a provision on amicus briefs); see also United Nations Commission on International Trade Law Arbitration Rules, G.A. Res. 65/22, U.N. Doc. A/RES/65/22 (Jan. 10, 2011) (demonstrating that the 2010 revised version of the UNCITRAL Arbitration Rules also contains no provisions on amicus briefs).

66. Petition for Participation as Non-Disputing Parties ๆ 3.1, 3.4, Chevron Corp. \& Texaco Petroleum Co. v. Ecuador, Case No. 2009-23 (Perm. Ct. Arb. 2010). The tribunal ruled that nonlitigants had no right to 
those peoples to seek to influence the decisions of the tribunal. Rather, the only way to get their perspective into the litigation would be to rely on Ecuador. Unfortunately, there is no guarantee that Ecuador (or any other country) will faithfully represent the views of particular interest groups within its borders, and it may have incentives to prioritize other concerns. ${ }^{67}$

International courts may not only directly affect rights and duties of nonlitigants, but they may also impact the interests of a variety of stakeholders. For example, the ICJ's ruling in the Pulp Mills case ${ }^{68}$ may affect corporations, individuals, and states where corporations intend to undertake development projects with possibly significant transboundary adverse impacts. The ICJ faced the question whether Uruguay violated the procedural and substantive requirements of the Uruguay River Statute, ${ }^{69}$ a bilateral treaty establishing a prior notification and consultation regime and a regulatory framework for limiting water pollution, after Uruguay authorized, constructed, and operated a pulp mill on its side of the River Uruguay. ${ }^{70}$ Within its judgment, the court asserted that transboundary environmental impact assessments are required by customary international law. ${ }^{71}$ The court's ruling may affect the rigor of standards for environmental impact assessments and, consequently, a company's choice to undertake a project or a state's decision to grant authorizations for construction and operation of facilities in a transboundary context. ${ }^{72}$ The decision may impact how international financial institutions and private banks evaluate loan applications for projects with transboundary impacts. Finally, it may affect individuals in both Uruguay and Argentina whose views may not have been represented by their states in the courtroom, perhaps by modifying economic opportunities or environmental conditions. The ICJ Statute and Rules of Procedure afford none of these nonstate stakeholders any right to appear before the court or to submit amicus briefs. ${ }^{73} \mathrm{~A}$ nonlitigating state may

file amicus curiae briefs during the jurisdictional phase. Procedural Order No. 8 ๆ 20, Chevron Corp. \& Texaco Petroleum Co. v. Ecuador, Case No. 2009-23 (Perm. Ct. Arb. 2011). The request does not appear to have been renewed at a later stage of the proceedings.

67. See Judith Kimerling, Indigenous Peoples and the Oil Frontier in Amazonia: The Case of Ecuador, Chevrontexaco, and Aguinda v. Texaco, 38 N.Y.U. J. INT'L L. \& POL. 413, 426-33 (2006) (discussing Ecuador's Amazon policy of "internal colonization" and development of oil reserves and its impact on indigenous communities); see also Brief for Fundación Pachamama and the International Institute for Sustainable Development as Amici Curiae Supporting Respondents \$ 4.7, Chevron Corp. \& Texaco Petroleum Co. v. Ecuador, Case No. 2009-23 (Perm. Ct. Arb. 2010) (describing sources criticizing Ecuador's conduct with respect to access to justice for indigenous peoples); Gerald P. Neugebauer III, Note, Indigenous Peoples as Stakeholders: Influencing Resource Management Decisions Affecting Indigenous Community Interests in Latin America, 78 N.Y.U. L. REv. 1227, 1230, 1237-40 (2003) (pointing to the Ecuadorian Amazon as an example of the insufficiency of "relying primarily on governmental mechanisms" to protect the human rights afforded to indigenous groups).

68. Pulp Mills on River Uruguay (Arg. v. Uru.), Judgment, 2010 I.C.J. 14 (Apr. 20).

69. Statute of the River Uruguay, Uru.-Arg., Feb. 26, 1975, 1295 U.N.T.S. 340.

70. Pulp Mills, 2010 I.C.J. $\uparrow \uparrow 122-23,67$.

71. Id. $ๆ 204$.

72. See id. IT 209-11, 223-25 (evaluating whether the specific actions taken by Uruguay complied with due diligence requirements for conducting environmental impact assessments).

73. ICJ Statute, supra note 22, art. 34 (providing that "[o]nly states may be parties in cases before" the ICJ). Interestingly, the ICJ's judgment stated, too, that none of the instruments invoked by Argentina supported a legal obligation to consult with affected populations. Pulp Mills, 2010 I.C.J. ๆ 216. 
intervene only if the court determines it has "an interest of a legal nature which may be affected by the decision in the case." 74 States do, however, have the right to intervene if the court is interpreting a treaty to which they are parties. ${ }^{75}$ These requests to intervene are rarely granted. ${ }^{76}$

In the same vein, several scholars have raised concerns or acknowledged the impact of international investment and trade law adjudications on human rights and the environment, and thereby, on rights and stakeholders, through ICSID and the WTO Dispute Settlement Body. Among these are former ICJ Judge Bruno Simma, who points out the concerns of states, civil society, and NGOs about the impact of international investment law on their rights and interests and attempts to put human rights in a more prominent place within investment treaty arbitration. ${ }^{77}$ In response to a question about human rights, the environment, and litigation at ICSID, SecretaryGeneral Meg Kinnear acknowledged that human rights may be linked to investment arbitration "when tribunals are looking at cases that arise in a certain context, particularly with regards to environmental issues" or when a party is defending an expropriation on the basis of police powers. ${ }^{78}$ Some have gone so far as to criticize ICSID for providing "almost a carte blanche for investor human rights abuses."79 The 2012 U.S. Model Bilateral Investment Treaty recognizes the interconnectedness of international investment law and, therefore, its adjudication, on health, safety, the environment, and labor rights. ${ }^{80}$ It also contains specific provisions on investment and the environment, investment and labor rights, and the transparency of investment proceedings. ${ }^{81}$ Similarly, many debate the WTO Dispute Settlement Body's impact on the environment, human health, human rights, and numerous stakeholders. ${ }^{82}$

74. ICJ Statute, supra note 22, art. 62.

75. Id. art. 63. The ICJ Statute provides that if states intervene under these circumstances, they are bound by the Court's interpretation of the treaty. Id. This raises the interesting theoretical question of whether states that do not intervene are also bound. Nonetheless, even if the ICJ Statute implies that they are not formally bound, the court's interpretations will undoubtedly shape perceptions of state obligations under the treaty.

76. See C.M. Chinkin, Third-Party Intervention Before the International Court of Justice, 80 AM. J. INT'L L. 495, 531 (1986) (arguing that the ICJ has "denied the mandatory language of Article 63 and interpreted Article 62 so narrowly" that state intervention does not seem presently feasible); Sean D. Murphy, Amplifying the World Court's Jurisdiction Through Counter-Claims and Third-Party Intervention, 33 GEo. WASH. INT'L L. REv. 5, 21-25 (2000) (discussing the few times that intervention has taken place at the ICJ).

77. Simma, supra note 5 , at 573, 575-76.

78. ICSID in the Twenty-First Century: An Interview with Meg Kinnear, 104 AM. SOC'Y INT'L L. PROC. 413, 424 (2010). Nonetheless, Secretary-General Kinnear asserted that ICSID is "not a facility that is adjudicating human rights." Id.

79. Noemi Gal-Or, The Investor and Civil Society as Twin Global Citizens: Proposing a New Interpretation in the Legitimacy Debate, 32 SuFFolK TRANSNAT'L L. REV. 271, 282 (2009).

80. Office of the U.S. Trade Representative \& U.S. Dep't of State, 2012 U.S. Model Bilateral Investment Treaty pmbl., http://www.ustr.gov/sites/default/files/BIT\%20text $\% 20$ for $\% 20$ ACIEP $\% 20$ Meeting.pdf.

81. Id. arts. 12, 13, 29.

82. See Gabrielle Marceau, The WTO Is Not a Closed Box, 100 AM. SOC'Y INT'L L. PROC. 29, 30-31 (2006) (discussing how the WTO often considers nontrade concerns when resolving trade disputes, including environmental, health, and religious factors); Joost Pauwelyn, The Transformation of World Trade, $104 \mathrm{MICH}$. L. REV. 1, 32 (2005) (explaining how the WTO's consideration of health and environmental standards as they relate to the world trade system affected governmental trade elites and businesses, as well as NGOs, consumers, and citizens at large); Gary P. Sampson, Is There a Need for Restructuring the Collaboration 
Traditional approaches to legitimacy recognize neither the impact of international courts on nonlitigants nor the changed role of international courts. International courts do not just decide one-time disputes between states. Rather, much of the time they are involved in advancing particular values or keeping states within a particular normative community. ${ }^{83} \mathrm{~A}$ number of international court judges appear to perceive themselves as advancing a set of values or creating communities around such values, not simply resolving one-time disputes. When he served as president of the Inter-American Court of Human Rights, Judge Thomas Buergenthal proposed that the court's purpose was to create a "climate ... wherein human rights disputes can be depoliticised" and where "governments learn to submit themselves to a Tribunal to have a case decided." $84 \mathrm{He}$ emphasized, too, the importance "of judges whose integrity and commitment to human rights is beyond question." 85 Although he rejected the proposition that judges can be policy-making activists, he suggested that "you can be an activist in terms of believing that law plays an important role in resolving some of the societal problems that create these terrible violations of human rights we've experienced." 86 Similarly, former ECHR Judge John Hedigan lauded the ECHR's role in promoting human rights throughout Europe, as follows:

I think that the individual is the most precious form in society. The relationship between the state and the citizen-the individual-lies at the very heart of civilization. That they're treated with decency and respect, can stand up and say their piece whenever they want, that they're not going to be tortured, or abducted, or imprisoned for their views or their religion-these are precious and vulnerable rights. I think the court is spreading those standards all over Europe. The things that are happening in this regard, and that have happened in Europe over the last half a century, are remarkable. ${ }^{87}$

In the same vein, the ECJ has been an important force in the constitutionalization of Europe. ECJ rulings "transformed the Treaty of Rome into a de facto constitution for the European Community." 88 Former president of the ECJ, Lord Mackenzie Stuart, acknowledged the ECJ's role in promoting European integration: "The foundation of

Among the WTO and UN Agencies so as To Harness Their Complementarities?, 7 J. INT'L ECON. L. 717, 721 (2004) (noting that "the WTO dispute settlement process finds itself dealing with cases relating to nontraditional trade areas such as the environment and public health."); Marjorie Cohn, The World Trade Organization: Elevating Property Interests Above Human Rights, 29 GA. J. INT'L \& COMP. L. 427, 431 (2001) (describing how the WTO consistently rules in favor of big business rather than in the interest of protecting the environment).

83. See Yuval Shany, Assessing the Effectiveness of International Courts: A Goal-Based Approach, 106 AM. J. INT'L L. 225, 246 (2012) (explaining how international courts advance the goals of the institutional regimes to which they are connected such as the European Union or WTO). Like domestic courts, international ones are involved in "social control." SHAPIRO, supra note 27, at 22, 26. Martin Shapiro proposes that courts have moved away from the ideal type of two litigants choosing a third person to resolve their disputes. Id. at 1 . Rather, courts-and judges-are associated with the imposition of particular substantive norms of those ruling the broader society. Id. at 22,26 . "Thus a major function of courts in many societies is a particular form of social control, the recruiting of support for the regime." $I d$. at 22.

84. STURGESS \& CHUBB, supra note 34 , at 534.

85. Id.

86. Id. at 118-19.

87. TERRIS ET AL., supra note 32, at 220 (emphasis added).

88. Alter \& Helfer, supra note 36 , at 564. 
the Community is an act of political will and if, from time to time, it is lacking, the court may, by an interpretive process here and there, deblock negotiations." 89 It is remarkable how explicit these judges are in recognizing their role in creating communities and promoting norms.

Although this Article focuses on noncriminal courts, examples abound in the realm of international criminal law as well. For example, the International Criminal Tribunal for the Former Yugoslavia (ICTY) has justified at least two decisions in light of the purposes of international humanitarian law. The ICTY Appellate Chamber rejected the defense of duress in a case involving crimes against humanity partly to effectuate the goals of international humanitarian law. ${ }^{90}$ When faced with a question with no clear legal answer, it "assert[ed] an absolute moral postulate which is clear and unmistakable for the implementation of international humanitarian law."91 Similarly, the ICTY Appellate Chamber in Prosecutor v. Tadic ${ }^{92}$ noted that its decision to characterize the conflict in Bosnia as "international" was "borne out by the entire logic of international humanitarian law," grounded on the notion of effectiveness and inspired by the aim of deterring deviation from its standards to the maximum extent possible."94 The underlying goals of the body of law at issue were a driving force in the ICTY's decision making.

\section{Why These Changes Render Traditional Approaches Anachronistic}

International courts shape the law prospectively and affect actors beyond the litigants immediately before the court. They are engaged in perpetuating values and maintaining normative communities. These acknowledged realities of international adjudication mandate taking a second look at traditional approaches to legitimacy such as consent and procedural fairness to litigants alone.

The state consent approach is flawed because it assumes international courts' exclusive role is to decide one-time disputes involving states and that a decision's impact is limited to the litigating parties. The state consent approach supposes that states are sovereign and independent, and therefore no court can judge them without their consent. Yet international court decisions affect nonlitigating states. Various

89. STURGESS \& CHUBB, supra note 34 , at 494 . Lord Stuart also noted that the court did so when it indicated it was unnecessary for the council to issue "directives about free movement of persons because the right was a fundamental one already inscribed in the Treaty." $I d$. He noted, however, that "it is a dangerous tendency . . . to think that the court can do more than it really can." Id.

90. Prosecutor v. Erdemovic, Case No. IT-96-22-A, Judgement of the Appeals Chamber, 17 4, 19 (Int'l Crim. Trib. for the Former Yugoslavia Oct. 7, 1997); Prosecutor v. Erdemovic, Case No. IT-96-22-A, Joint Separate Opinion of Judge McDonald and Judge Vohrah, fा 80, 83 (Int'l Crim. Trib. for the Former Yugoslavia Oct. 7, 1997).

91. Erdemovic, Case No. IT-96-22-A, Joint Separate Opinion of Judge McDonald and Judge Vohrah, ๆT 80, 83 (emphasis added). The Judgment of the Appeals Chamber incorporates the reasoning of Judge McDonald and Judge Vohrah's joint separate opinion on the issue of whether duress constitutes a complete defense to a charge of crimes against humanity. Erdemovic, Case No. IT-96-22-A, Judgement of the Appeals Chamber, I 19.

92. Case No. IT-94-1-A, Judgement of the Appeals Chamber, (Int'l Crim. Trib. for the Former Yugoslavia July 15, 1999)

93. Tadić, Case No. IT-94-1-A, Judgement of the Appeals Chamber, $\$ 96$.

94. Id. 
international judges like those quoted above appear to see themselves as responsible for establishing and maintaining a kind of international rule of law. Courts routinely change the international legal obligations of nonlitigating states even if those states did not consent to jurisdiction. Even if the relevant treaty allows a state to opt out of compulsory jurisdiction, a decision can still be used as a focal point for domestic and international actors to pressure the state. Under the traditional state consent approach, making new law applicable to all states should render a court illegitimate. But if a court's job is to promote human rights, then a decision that promotes human rights may be legitimacy enhancing, regardless or even because of its impact on nonlitigating states.

The state consent approach to legitimacy is flawed for another reason. Nonstate actors' rights and duties may be directly affected by international courts, yet their consent appears irrelevant. The traditional story is that states were the only subjects, or legal persons, addressed by international law. Only states could possess rights and duties to the exclusion of nonstate actors. ${ }^{95}$ Other legal persons are widely recognized today, such as international organizations, ${ }^{96}$ individuals, ${ }^{97}$ and corporations. ${ }^{98}$ State consent to jurisdiction matters to legitimacy, at least in part, because adjudication affects states' rights and obligations. But even when adjudication affects a nonstate actor's rights and obligations, the nonstate actor plays no role in consenting to its jurisdiction. Although states presumably represent their people when they decide to join a dispute resolution regime, some states are undemocratic, barely democratic, or represent only the views of empowered elites. Even in representative states, people's views may change over time, and it may be impractical or impossible for a state to

95. Janne Elisabeth Numan, The Concept of International Legal Personality: AN InQuiry INTO THE HISTORY AND THEORY OF INTERNATIONAL LAW 10 (2005).

96. See Reparation for Injuries Suffered in Service of United Nations, Advisory Opinion, 1949 I.C.J. 174, 187 (Apr. 11) (holding that the United Nations, acting as an organization, may pursue an international claim against a state government to obtain reparations for damage suffered); Vienna Convention on the Law of Treaties Between States and Intemational Organizations, Mar. 21, 1986, 25 I.L.M. 543; Responsibility of International Organizations, Rep. of the Int'l Law Comm'n, 63d Sess., Apr. 26-June 3, July 4-Aug. 12, 2011, U.N. Doc. A/66/10; GAOR, 66th Sess., Supp. No. 10 (2011) (discussing the responsibilities of international organizations under international law).

97. See THEODOR MERON, THE HUMANIZATION OF INTERNATIONAL LAW 1 (2006) (describing the impact of human rights and humanitarian law on many other parts of international law and asserting that "[t]he humanization of public international law under the impact of human rights has shifted its focus above all from State-centered to individual-centered"); MARIO PROST, THE CONCEPT OF UNITY IN PUBLIC INTERNATIONAL LAW 5 (2012) (describing the shift of the role of individuals in international law from "mere objects" to "holders of international rights that are actionable in court"). International human rights law bestows individuals with a panoply of rights. American Convention on Human Rights arts. 4, 5, 6, Nov. 22, 1969, 1144 U.N.T.S. 123; Intemational Covenant on Civil and Political Rights, supra note 57, arts. 18, 21; International Covenant on Economic, Social and Cultural Rights arts. 6, 11, 15, adopted Dec. 16, 1966, 993 U.N.T.S. 3; ECHR, supra note 24 , arts. 3,9 . Also, individuals have standing to pursue claims against states for violating human rights treaties. E.g., Statute of the Inter-American Commission on Human Rights, O.A.S. Res. 447 (IX0/79) (1979); Convention for the Protection of Human Rights and Fundamental Freedoms, supra note 24, arts. 19-51; Protocol to the African Charter on Human and Peoples' Rights on the Establishment of an African Court of Human and People's Rights art. 30, June 9, 1998, Doc. OAU/LEG/EXP/AFCHPR/PROT(III).

98. For example, corporations have the right to sue states in NAFTA and ICSID. ICSID Convention, supra note 23, art. 25; North American Free Trade Agreement ch. XI, U.S.-Can.-Mex., Dec. 17, 1992, 32 I.L.M. 289; PROST, supra note 97, at 5. 
disentangle itself from a dispute resolution system. If a state consented fifty years ago, does that confer legitimacy on a court today? The consent principle has itself lost force, and many scholars of international legitimacy believe it is at most a weak basis for the legitimacy of international institutions. ${ }^{99}$

Although his focus is on domestic courts, perhaps Martin Shapiro provides an alternative formulation of this critique. Shapiro declared that domestic courts rarely conform to the ideal type of "(1) an independent judge applying (2) preexisting legal norms after (3) adversary proceedings in order to achieve (4) a dichotomous decision in which one of the parties was assigned the legal right and the other found wrong." 100 Instead, he argues that consent and the independent judge have been replaced by judicial office and law. ${ }^{101}$ In other words, individuals no longer choose the adjudicator and rules to be applied, but rather, they are subject to society's choice of adjudicator as well as society's values and preferences as expressed by its laws. The same goes for international courts. Consent becomes less meaningful as the foundation of international courts' legitimacy when jurisdiction is essentially compulsory or consent was expressed fifty years ago. And international courts may promote values that diverge from what states consented to in the first place. The point is that while state consent may matter for legitimacy, it is an insufficient basis for legitimacy standing on its own.

The procedural fairness to litigants approach to legitimacy, too, is difficult to reconcile with the realities of international adjudication. Again, international court decisions affect nonlitigants. Yet the procedural fairness approach as traditionally understood leaves no role for them. Taking the most extreme example, imagine an individual whose rights and duties under international law are being adjudicated by the decision of an international court. Assume the individual has no standing, has no right to file an amicus brief, and proceedings are closed to the public. If all other requirements are met, such a court is legitimate according to the traditional procedural faimess approach. The focus on procedural fairness to litigants alone leaves an enormous blind spot in assessments of normative legitimacy.

The procedural fairness approach assumes the existence of neutral or impartial adjudicators and benches or panels of adjudicators. Such adjudicators presumably view facts objectively, favor neither party to a dispute, and have no goals besides dispute resolution. Yet the reality is that adjudicators introduce outside interests into adjudication all the time, such as those of the institution or actor that appoints them. ${ }^{102}$

99. Cesare P.R. Romano, The Shift from the Consensual to the Compulsory Paradigm in International Adjudication: Elements for a Theory of Consent, 39 N.Y.U. J. INT'L L. \& POL. 791, 794-95 (2007); Meyer \& Sanklecha, supra note 13, at 4-5; Richard Falk \& Andrew Strauss, On the Creation of a Global Peoples Assembly: Legitimacy and the Power of Popular Sovereignty, 36 STAN. J. INT'L L. 191, 208 (2000); Allen Buchanan, The Legitimacy of International Law, in THE PHILOSOPHY OF INTERNATIONAL LAW 79, 90-91 (Samantha Besson \& John Tasioulas eds., 2010); Wolfrum, supra note 16, at 9; Tasioulas, supra note 13, at 20-21.

100. SHAPIRO, supra note 27 , at 1 .

101. Id. at 18.

102. Martin Shapiro discusses these interests in the domestic context:

When the two parties must go to a third who is an officer, it is as evident to them as to the observer that they are no longer going to a disinterested third. Instead they are introducing a third interest: 
These may include preservation of power relationships, human rights or free trade promotion, protection of state sovereignty, environmental concerns, and favoring peaceful conflict resolution over justice, or vice versa. Judges' professional and personal identities and goals may also influence adjudicatory outcomes. ${ }^{103} \mathrm{~A}$ nearsighted focus on procedural fairness solely to litigants ignores the recognized and evolving roles, objectives, and impacts of international courts.

\section{A NEW APPROACH TO NORMATIVE LEGITIMACY}

The traditional approach to normative legitimacy for international courts is deeply flawed. State consent and procedural fairness to litigants alone are insufficient to ground the legitimacy of international courts. Yet crafting a new approach presents daunting challenges. First, such a theory must recognize the new realities of international adjudication, including that international adjudication affects the rights, responsibilities, and interests of nonlitigating states and nonstate actors, and international courts do not solely decide one-time disputes but rather are involved in creating norms over time. Merely acknowledging in a footnote that states are no longer the sole subjects of international law is insufficient. ${ }^{104}$ The theory must incorporate these realities to be useful. "Prescription aims at a particular normative goal, but it must take into account present reality in order to achieve that goal." 105

Simultaneously, despite all the changes in the role of nonstate actors in the international system and the growing implications of international court proceedings for nonlitigants, the theory must still recognize that states may withdraw their consent to jurisdiction from many international courts or simply stop using them if it becomes unduly burdensome to do so. The theory must be sensitive to the practical reality that states continue to play a pivotal role in the success of international dispute resolution. Without states, there would be no international courts. As Lukas H. Meyer and Pranay Sanklecha point out, if a normative theory fails to take into account empirical realities, its principles are useless ("practical irrelevance"). ${ }^{106}$ Yet giving politics the upper hand in crafting normative theory may result in the endorsement of injustice ("adaptive preference"). ${ }^{107}$ This Article seeks to strike some imperfect balance between the two.

A second challenge to building a coherent theory is the diversity of the dozens of international courts operating today. They differ on the breadth of their subject matter

that of the government, the church, the landowner, or whoever else appoints the official.

Id.

103. See, e.g., Nienke Grossman, Sex on the Bench: Do Women Judges Matter to the Legitimacy of International Courts?, 12 CHI. J. INT'L L. 647, 656-60 (2012) (suggesting that judges' gender may, at times, influence their decision making).

104. See, e.g., FERNANDo R. TEsón, A PHILOSOPHY OF INTERNATIONAL LAw 1 (1998) ("Although it is understandably hard for lawyers to forsake the statist assumptions of classic international legal discourse, new times call for a fresh conceptual and ethical language."); Meyer \& Sanklecha, supra note 13, at 14 (arguing that an exclusive focus on states seems "at the least, incomplete, leading naturally to the question of how to accommodate the widened range of actors within any systematic explanation of what justice (and legitimacy) involve at the international level").

105. Bodansky, supra note 9 , at 314.

106. Meyer \& Sanklecha, supra note 13 , at 19.

107. Id. 
jurisdiction, whether their jurisdiction is compulsory, the standing they afford to nonstate actors, the transparency of their procedures, and the availability of enforcement mechanisms. And "[w]hat is required in order to legitimise an institution may vary depending on how much authority it is exercising, the kind of authority it is exercising, and the kinds of issues it is exercising authority over." 108 Consequently, a theoretical framework must be broad enough to accommodate the various courts within its scope, yet narrow and concrete enough to be useful. The goal, after all, is to be able to use the theory to evaluate the legitimacy of various international courts, to learn from the differences among courts, and to craft legitimacy-enhancing institutional reforms.

A third challenge to creating a theory of justified authority for international courts is the scarcity of universal objective principles in a world of seven billion people. Normative legitimacy is supposed to be grounded in objective principles, while sociological legitimacy depends on perceptions and is agent relative. ${ }^{109}$ State consent is an attractive source of legitimacy because it allows states to choose for themselves what values they will ascribe to. To the extent the theory grapples with the relationship between the justice of institutional outputs and legitimacy, it must acknowledge the narrowness of consensus on the meaning of "justice." 110 Further, a theory of normative legitimacy should also acknowledge that such a consensus may change over time. ${ }^{111}$

A fourth hurdle is distinguishing between what matters to legitimacy and what is simply good policy for reasons unrelated to legitimacy. What underpins legitimacy, as opposed to the rule of law, justice, or something else? One way that scholars have systematically approached legitimacy theory is by examining it through the lens of inputs, process, and outputs. State consent and procedural fairness to litigants fall into the input and process categories, respectively, while justice is linked to outputs. ${ }^{12}$ This Article proposes both procedural and substantive requirements for legitimacy.

Despite these and other challenges, building a new theory is vital. Applying an outmoded approach to legitimacy engenders a false sense of security about international courts' health and viability. Also, enough commonality exists among international courts to merit a fieldwide theory. At the highest level of generality, all of these institutions were created by states to assist in the resolution of disputes governed by international law. They are staffed by nationally diverse persons who are knowledgeable in international law. They find facts, identify and interpret relevant rules, fill in gaps in the law when necessary, and apply rules to facts. Building a theory of legitimacy that spans international courts can push scholars and court reformers to think more broadly and deeply about international adjudication. Further, it can

108. Bodansky, supra note 9 , at 316.

109. E.g., Bodansky, supra note 8, at 601; Grossman, supra note 10, at 115-16.

110. See Buchanan \& Keohane, supra note 7, at 412 (discussing disagreement on the meaning of "justice").

111. Altematively, one could disregard whatever consensus exists on the meaning of justice and attempt to deduce first principles independently of consensus. This Article prefers to rely on states' common understanding to avoid charges of "practical irrelevance," while remaining aware of the risk. Meyer \& Sanklecha, supra note 13, at 19. Further, virtually all universally held beliefs about justice are likely to reflect first principles to some extent.

112. E.g., Wolfrum, supra note 16 , at 6-7. 
encourage the imagination and evaluation of institutional reforms, which may enhance these institutions' legitimacy. Without legitimacy, international courts, especially those with weak enforcement mechanisms, are doomed to irrelevance and ineffectiveness.

In spite of the difficulties in crafting a new theory of normative legitimacy, this Section proposes one. First, Part III.A sets forth a broader vision of procedural fairness that includes both stakeholders and rights holders. The remainder of Section III describes substantive requirements; Part III.B discusses justice, while Part III.C is concerned with faithfulness to the object and purpose of the norms being interpreted and applied. The hope is that this theory will serve as a starting point for future debate and discussion about the normative legitimacy of international courts.

\section{A. Reimagining Procedural Fairness}

Legitimacy requires that international courts allow nonlitigants to participate in international court proceedings in at least two instances. First, when an international court is deciding a dispute that adjudicates a nonlitigant's international rights and obligations, the nonlitigant must have a fair and impartial hearing. Widely recognized notions of due process support this proposition. Second, when an international court is either acting as an organ of global administrative law or is making law, nonlitigating stakeholders whose interests are implicated must have the opportunity to influence outcomes. This argument is grounded in democratic theory.

\section{Right to a Hearing in Dispute Resolution Proceedings}

Courts must be procedurally fair to be legitimate. The hallmark of procedural fairness is affording an impartial hearing to those whose rights and duties are at issue. There is no difference in adjudication at the domestic and international levels that necessitates a different rule at the international level, except when one of the litigants adopts the views of a third-party entitlement holder. Individuals in particular have a strong basis in international human rights law for the right to a fair and impartial hearing when their rights and obligations are being adjudicated at the international level. Nonetheless, international courts must grant hearings only if a legal person can show that its rights or duties are being adjudicated by the court in the pending dispute and there is broad consensus as to the existence and scope of those rights and duties.

\section{a. International versus domestic courts and the right to a hearing}

Procedural fairness is an integral part of legitimate adjudication because it allows open-minded judges to consider equally the views of the parties whose rights and duties are at stake. Conversely, it provides entitlement holders equal opportunities to attempt to influence the outcome in a case that directly implicates them. There is no difference in the adjudicative function at the international and domestic levels that justifies a different relationship between procedural faimess and legitimate adjudication at the international level. ${ }^{113}$ Both an international court deciding the course of a

113. See Paul Mahoney, The International Judiciary - Independence and Accountability, 7 L. \& PRAC. INT'L CTS. \& TRIBUNALS 313, 317 (2008) (making an analogous argument about judicial independence at the national and international levels). 
maritime boundary among three states and a domestic court deciding the property line between three houses must provide all sides with equal and unbiased opportunities to present their arguments. The ICJ has itself recognized the importance of including all states whose rights and duties are necessarily adjudicated in a particular case. In Monetary Gold Removed from Rome in 1943 (Italy v. France, United Kingdom, Northern Ireland, and United States), ${ }^{114}$ the ICJ dismissed Italian claims for want of jurisdiction because adjudication required a determination of Albania's international legal responsibility, and Albania had not consented to the court's jurisdiction. ${ }^{115}$ Whether the court is international or domestic or whether states or nonstate actors are involved is irrelevant. What matters is that a judicial institution is deciding a dispute among a set of entitlement holders, and all of them must be heard for the procedural fairness requirement to be met. If a court refuses to listen to one of them, its legitimacy is in peril.

A state's ability to access and participate in judicial proceedings on behalf of its nationals does not obviate the need for nonstate actors to represent themselves. First, there is no guarantee that their views will be represented. Governments may be undemocratic, unrepresentative, or even if democratic, guided by a small subset of elites with unique interests far removed from those of much of the population. Also, there may be transnational groups with rights being adjudicated in a dispute who are not represented by a state. For example, imagine a border dispute involving two states and a people who lives in both states but constitutes a majority in neither. Neither state may choose to represent that people's views during litigation. Procedural fairness requires that those whose entitlements are being adjudicated have the opportunity to advocate for their rights.

Nonetheless, if an entitlement holder's position is being represented by a litigant - if it adopts the entitlement holder's views - then procedural fairness does not require a separate hearing. For example, if Georgia files suit against Russia in the ICJ for violations of the Convention on the Elimination of Racial Discrimination, then those allegedly suffering racial discrimination as a result of Russia's conduct need no separate hearing. Georgia is representing their views directly. In other words, procedural fairness requires a third-party hearing only if the state refuses to or cannot make the entitlement holder's case in its own presentation to the international court.

\section{b. The right to a hearing for individuals}

Additionally, the right to an impartial hearing for individuals, as opposed to other subjects of international law, can be grounded in international human rights law. Several widely ratified international treaties and customary international law require states to provide persons whose rights are being adjudicated with an impartial hearing in the domestic context or due process rights. Global and regional treaties and the Universal Declaration of Human Rights seek to guarantee the right of individuals to access and participate in judicial proceedings when their rights and obligations are at issue. The International Covenant on Civil and Political Rights (ICCPR) provides that

114. Preliminary Question, 1954 I.C.J. 19 (June 15).

115. See Monetary Gold, 1954 I.C.J at 32-33 ("To adjudicate upon the international responsibility of Albania without her consent would nu counter to a well-established principle of international law."). 
"[i]n the determination of any criminal charge against him, or of his rights and obligations in a suit at law, everyone shall be entitled to a fair and public hearing by a competent, independent and impartial tribunal established by law." 116 The right to a fair hearing is of such high stature that the Human Rights Committee, the expert body charged with the ICCPR's interpretation, considers reservations to it inconsistent with the object and purpose of the treaty as a whole. ${ }^{117}$ Similarly, the American Convention on Human Rights states:

Every person has the right to a hearing, with due guarantees and within a reasonable time, by a competent, independent, and impartial tribunal, previously established by law, in the substantiation of any accusation of a criminal nature made against him or for the determination of his rights and obligations of a civil, labor, fiscal, or any other nature. ${ }^{118}$

The European Convention provides: "In the determination of his civil rights and obligations or of any criminal charge against him, everyone is entitled to a fair and public hearing within a reasonable time by an independent and impartial tribunal established by law." 19 The African (Banjul) Charter on Human and Peoples' Rights states that "[e]very individual shall have the right to have his cause heard." 20 This right includes "the right to an appeal to competent national organs against acts of violating his fundamental rights as recognized and guaranteed by conventions, laws, regulations and customs in force" and "the right to be tried within a reasonable time by an impartial court or tribunal." 121 The Convention on the Rights of the Child, too, grants a child the right to express his or her views "freely in all matters affecting the child," and to this end, "the child shall in particular be provided the opportunity to be heard in any judicial and administrative proceedings affecting the child, either directly, or through a representative or an appropriate body." 122

The Universal Declaration of Human Rights, too, supports the proposition that individuals should have the opportunity to participate in the adjudication of their rights. It provides that every person is entitled to "a fair and public hearing by an independent and impartial tribunal, in the determination of his rights and obligations and of any criminal charge against him." 23 The Universal Declaration has the status of customary international law and is an authoritative interpretation of the human rights provisions of

116. International Covenant on Civil and Political Rights, supra note 57, art. 14. One hundred sixtyseven states are parties to this treaty. United Nations, Status of Treaties, International Covenant on Civil and Political Rights 1, http://treaties.un.org/doc/Publication/MTDSG/Volume\%201/Chapter\%20IV/IV-4.en.pdf.

117. See U.N. Human Rights Comm., General Comment No. 32, ๆ 5, U.N. Doc. CCPR/C/GC/32 (Aug. $23,2007)$ (" $[\mathrm{A}]$ general reservation to the right to a fair trial would be incompatible with the object and purpose of the Covenant.").

118. American Convention on Human Rights, supra note 97, art. 8(1).

119. ECHR, supra note 24, art. 6(1).

120. African [Banjul] Charter on Human and Peoples' Rights art. 7, June 27, 1981, 1520 U.N.T.S. 217.

121. Id.

122. Convention on the Rights of the Child art. 12, adopted Nov. 20, 1989, 1577 U.N.T.S. 3. One hundred ninety-three states are parties to this convention. United Nation, Status of Treaties, Convention on the Rights of the Child 1, http://treaties.un.org/doc/Publication/MTDSG/Volume\%20V/Chapter\%20IV/IV11.en.pdf.

123. Universal Declaration of Human Rights, supra note 57, art. 10. 
the United Nations Charter. ${ }^{124}$

Although these instruments generally refer to the right of individuals to a fair and impartial hearing in a national court or tribunal, there is no difference in the adjudicative function that justifies limiting the right to a fair and impartial hearing only to those whose rights are being adjudicated domestically. ${ }^{125}$ Again, litigants may not represent the views of other entitlement holders. Further, it is difficult to argue against the proposition that international adjudication should meet minimum due process requirements found in human rights instruments. ${ }^{126}$ In this vein, the Universal Declaration of Human Rights urges the progressive implementation of measures "national and international" to secure the observance of human rights, which include the right to a fair hearing. ${ }^{127}$ Just as legitimacy at the domestic level requires participation of those whose rights and duties are being adjudicated, so too does legitimacy at the international level. Giving courts authority to adjudicate the rights and obligations of voiceless rights holders is a serious threat to their legitimacy and fails to account for the wide recognition of individuals as subjects of international law. When international courts adjudicate the rights and duties of individuals, basic notions of due process and international human rights law require the provision of some sort of hearing.

\section{c. What kind of right requires a hearing?}

Procedural fairness requires a hearing only if the legal person can show that its international rights or duties are being adjudicated by the court in the pending dispute, and there is broad consensus as to the existence and scope of those rights and duties.

Individuals possess a wide range of rights under the laws of their own states, as well as rights and duties derived from various areas of international law, including human rights, investment, and criminal law. Only when an international court is adjudicating a person's entitlements under international law is a hearing in an international court necessary. Domestic courts are best poised to interpret their own law because of their knowledge and experience. Also, international courts lack the authority to make judgments concerning violations of domestic law. For example, no hearing is required for an individual at the international level because her domestic civil rights are potentially harmed by the decision of an international court. Concretely, individuals in Uruguay and Argentina would have no right to a hearing before the ICJ in the Pulp

124. Antonio Augusto Cancado Trinidade, Introductory Note, Universal Declaration of Human Rights, Audiovisual Library of International Law, http://legal.un.org/avl/ha/udhr/udhr.html; Thomas M. Franck, The Emerging Right to Democratic Governance, 86 AM. J. INT'L L. 46, 61 (1992).

125. See Mahoney, supra note 113, at 317 (arguing that there is "no discemible reason" that the principles governing domestic adjudicative bodies would not govern international adjudicative bodies).

126. KLABBERS ET AL., supra note 15, at 128 . Although this argument is frequently made in international criminal court circles, it is virtually absent in international civil court ones. See, e.g., David Luban, Fairness to Rightness: Jurisdiction, Legality, and the Legitimacy of International Criminal Law 13-16 (Georgetown Univ. Law Ctr., Working Paper No. 67, 2008) (discussing the link between legitimacy and procedural faimess on international criminal tribunals).

127. Universal Declaration of Human Rights, supra note 57, pmbl., art. 10. Article 28 provides that "[e]veryone is entitled to a social and international order in which the rights and freedoms set forth in this Declaration can be fully realized." Id. art. 28. 
Mills case unless they could allege a violation of individual international legal rights. Procedural fairness does not require international courts to afford a hearing to someone whose domestic legal rights alone are at issue.

A person can demand a hearing under this theory only if he or she can show broad consensus regarding the existence and scope of the asserted international legal right or duty. By requiring those who seek a hearing to demonstrate that the right or duty asserted is accepted by a significant majority of the international community, or the relevant regional community of states, international courts cannot be charged with applying unfair or unknown standards to state behavior. For example, clarity and consensus are lacking concerning the meaning and legal status of several purported rights. Numerous international human rights instruments lay out dozens of rights, often with vague and aspirational language. Not all states have ratified all the relevant treaties, and many have made numerous reservations. Saudi Arabia's understanding of human rights may be very different from Norway's. Also, their understandings may change over time. To decide if broad consensus exists about the existence and scope of a right, a court could look at the number of states that are parties to treaties establishing the right and reservations to it, commentary by authoritative treaty bodies, state practice, opinions of relevant regional and state courts, statements by states and experts in the field, and resolutions passed in international organizations.

These factors strictly limit the situations in which a legal person can obtain a hearing. Two examples are useful to understand the circumstances in which a hearing is required. Take a border dispute between two countries where an ethnic minority spans the border. If the international court decides on the course of the border, it will de facto adjudicate the right of self-determination of the minority group. If neither state chooses to argue the position of the ethnic minority, and broad consensus exists concerning the status and core meaning of the right to self-determination, then the minority group must have a right to be heard during the course of the adjudication.

What about the Chevron-Ecuador litigation? ${ }^{128}$ Employing the approach set forth in this Part, the PCA would have needed to determine whether that litigation would de facto adjudicate the international legal rights of indigenous peoples. The PCA would consider a number of factors, including whether consensus exists as to the scope of the international legal rights allegedly at issue. Also, if Ecuador is adopting the same arguments as the indigenous peoples seeking a hearing as part of its response to the litigation, then the PCA could reject their request for a hearing. These can be high bars. It is difficult to make a judgment as to how a court might come out with respect to Fundación Pachamama and the International Institute for Sustainable Development, two NGOs that submitted petitions for participation as amici in the jurisdictional phase of the litigation, because the petitions were not drafted with these standards in mind. ${ }^{129}$ Nonetheless, they argue that a decision of the PCA could affect indigenous peoples' international legal rights to access justice. ${ }^{130}$

128. See supra notes 60-67 and accompanying text for a discussion of Chevron v. Ecuador.

129. See supra note 65-66 and accompanying text for an explanation of the right to file amicus curiae briefs during the jurisdictional phase.

130. Brief for Fundación Pachamama and the International Institute for Sustainable Development as Amici Curiae Supporting Respondents, supra note 67, $\uparrow 4.8$ 


\section{d. What kind of hearing is required?}

Let us assume that an individual meets the narrow threshold requirements to obtain a hearing in an ongoing dispute being adjudicated by an international court. What kind of hearing is required? Individuals must be afforded an opportunity to present views about the implications of the case for their rights and to have an impartial court address those views in its decision making. More specifically, individuals must have the chance to provide their perspectives to the court on how international law relevant to their rights and duties constrains the actions of the litigating parties.

In order to present views, persons must have access to both the oral and written pleadings of the parties at the time they are presented to the court in a language accessible to them. They must be permitted to attend hearings of the court and review any decisions the court has made in the case. The court could decide whether to allow the presentation of views in writing or orally.

The right to a hearing is meaningless without an impartial tribunal. Judges' identities, how and by whom they were appointed, their education, their professional reputation, and whether they hope to secure appointments in the future may influence judicial decision making. ${ }^{131}$ What would a court impartial to both states and other rights holders look like? If only states are involved in judicial selection, judges may prize states' rights over individual ones, or they may have a narrower view of which kinds of rights should receive the attention of international courts. States could modify the qualifications requirements for international judges, draft new judicial oaths of impartiality, or create nominating committees for international courts that include nonstate actors. They could include, or continue to include, representativeness requirements within courts' statutes. ${ }^{132}$ They could also allow individuals the right to name their own judge to a tribunal.

Other models are possible. The point is that once it is recognized that nonlitigants' rights and duties are being adjudicated in international courts, they must have the opportunity to present their views to an impartial tribunal to satisfy the procedural faimess requirements of legitimacy.

\section{e. What if a conflict arises?}

In the narrow circumstances where a nonstate third party may have rights being adjudicated in an international court proceeding, how should a court address the new party's concerns? States have a wide range of obligations to each other that touch on different substantive areas of international law such as trade, use of force, environmental law, and human rights law. At the same time, these obligations are intended to regulate states' conduct with respect to other states, as well as other international legal persons, such as individuals, corporations, and sometimes international organizations. What if these obligations conflict? Should some obligations

131. E.g., Simma, supra note 5, at 576-77 (sensing "a bit of reticence . . vis-à-vis human rights" in the foreign investment and arbitration profession and questioning whether it "might be in the investment arbitrators' genes" because most have a private or commercial rather than public law background).

132. See Grossman, supra note 105 , at $668-70$ (discussing sex representativeness requirements on various international courts). 
take precedence over others? As the 256-page Report of the Study Group of the International Law Commission on Fragmentation of International Law demonstrates, these are complex questions that merit further study and reflection. ${ }^{133}$ At a minimum, this Article proposes in Part III.B that international courts must prize some core set of human rights above all other obligations of the state.

\section{Stakeholder Participation in Judicial Law or Policy Making}

Must international courts provide the opportunity to participate to those who have interests in what direction law or policy takes, but no specific right or duty being adjudicated in any particular dispute? Because state consent and procedural fairness to litigants alone are insufficient to justify the authority of international courts engaging in law or policy making, one way international courts can justify their authority is by providing stakeholders with participation rights.

Democratic theory can provide a justification for the exercise of public authority of international courts. ${ }^{134}$ Democratic models are many and varied, but they generally include elements of representation, participation, accountability, and deliberation. ${ }^{135}$ Although one could analyze the applicability and role of all of these elements in justifying the authority of international courts, this Article limits itself to a discussion of one of the most fundamental "building block[s] of democracy"-participation by those affected. ${ }^{136}$ Participation in the conduct of public affairs is an integral part of democracy. "[D]emocracy requires that all those whose basic interests are affected by policy decisions are able to participate directly or indirectly in the process of making them."137 Participation not only allows those affected to influence judicial processes, but it also provides opportunities to monitor what is taking place and to utilize mechanisms of control and accountability outside the courthouse.

But how does one justify the application of this democratic principle to international institutions and to international courts in particular? Different states have different approaches to governance. Even if one ascribes to democracy at the domestic level, it does not easily or automatically apply at the international one. For example, the demos is more readily identifiable at the state level but not necessarily at the international one. ${ }^{138}$ Further, democratic principles are generally applied to political

133. See generally Fragmentation of International Law: Difficulties Arising from the Diversification and Expansion of International Law, Rep. of the Study Group of the Int'l Law Comm'n, 58th Sess., May I-June 9, July 3-Aug. 11, 2006, U.N. Doc. A/CN.4/L.682; GAOR, 58th Sess., Supp. No. 10 (2006).

134. See Armin von Bogdandy \& Ingo Venzke, On the Democratic Legitimation of International Judicial Lawmaking, 12 GERMAN L.J. 1341, 1343 (2011) (contending that "[d]emocratic justification is ineluctable for the exercise of any public authority").

135. See Gráinne De Búrca, Developing Democracy Beyond the State, 46 Colum. J. Transnat'L L. 221, 227 (2008) (discussing participation and representation of affected parties); J.H.H. Weiler, The Geology of International Law - Governance, Democracy and Legitimacy, 64 Heidelberg J. Int'l L. 547, 560 (2004) (referencing representation, accountability, and deliberation as democratic values).

136. De Búrca, supra note 135 , at 227.

137. Samantha Besson, Institutionalising Global Demoi-cracy, in LegITIMACY, JUSTICE AND PUBLIC INTERNATIONAL LAW, supra note 13, at 66, 66 .

138. See Weiler, supra note 135 , at 560 (asserting that while a demos is presumed in states, there is no clear demos at the international level). 
institutions such as legislatures, not to courts. Finally, applying democratic principles to international institutions may fail to recognize that international institutions lack the social and political conditions for democracy at the domestic level, such as an individual right to vote, majoritarian decision making, a global public in constant communication over public issues, free press and media, and institutions to check abuses of power. ${ }^{139}$ These arguments may explain why so few have grappled with the democratic legitimacy of international tribunals. ${ }^{140}$

As this Part argues, despite differences in state approaches to governance, numerous global and regional treaties and soft law instruments support the proposition that individuals, and sometimes even NGOs, have a right to take part in the conduct of public affairs. Undemocratic and unrepresentative states, as well as transnational constituencies, make it necessary to effectuate opportunities for participation at the international level, although these instruments generally refer to the domestic one. The activities of international courts are close enough to the conduct of public affairs, at least some of the time, to necessitate some kind of democratic justification. Further, because international courts are not embedded in a constitutional framework, the need for democratic justification is particularly salient. A number of institutional changes are necessary to bring about participation at the international court level.

Importantly, the objective is not to recreate domestic democracy at the international level to achieve legitimacy, nor to apply the principles of domestic democracy in the same way to international courts as to domestic legislatures. For example, participation may not take the same form at the domestic and international levels. It may apply to different kinds of institutions in different ways. Instead, the goal is to find some way to legitimate the power of institutions that exercise authority over both state and nonstate actors, yet where the latter may play no role whatsoever in decision-making processes. In J.H.H. Weiler's words:

What is required is both a rethinking of the very building blocks of democracy to see how these may or may not be employed in an international system which is neither State nor Nation and to search for alternative legitimating devices which would make up for the non applicability of some of the classical institutions of democracy where that is not possible. ${ }^{141}$

Participation in the conduct of public affairs is one such building block. ${ }^{142}$

\section{a. Participation in the conduct of public affairs}

Not only democratic theory discusses the importance of the participation of those affected in the formulation of policies that impact them. Numerous global and regional international treaties and soft law instruments articulate a right to take part in the conduct of public affairs. For example, the Universal Declaration of Human Rights

139. Buchanan \& Keohane, supra note 7, at 416.

140. See KLABBERS ET AL., supra note 15, at 150 . But see von Bogdandy \& Venzke, supra note 14 , at 979.

141. Weiler, supra note 135 , at 561 .

142. See De Búrca, supra note 135, at 227 (identifying the "fullest possible participation and representation of those affected" as "one particular building block of democracy"). 
provides that governments should reflect the "will of the people,"143 and that "[e]veryone has the right to take part in the government of his country, directly or through freely chosen representatives" and "the right of equal access to public service in his country."144 The ICCPR similarly states that "[e]very citizen shall have the right and the opportunity ... [t]o take part in the conduct of public affairs, directly or through freely chosen representatives." 145 The Human Rights Committee described this article of the ICCPR as addressing "the right of individuals to participate in those processes which constitute the conduct of public affairs." 146 It noted that the conduct of public affairs is "a broad concept which relates to the exercise of political power, in particular the exercise of legislative, executive and administrative powers. It covers all aspects of public administration, and the formulation and implementation of policy at international, national, regional and local levels."147

Regional human rights treaties as well as International Labour Organization Convention 169 recognize the importance of the right to participate in public affairs. For example, the American Convention on Human Rights states that every citizen has the right to "take part in the conduct of public affairs, directly or through freely chosen representatives." 148 The African Charter contains similar language. ${ }^{149}$ International Labour Organization Convention 169 also imposes obligations on states to consult indigenous peoples in formulating policies that concern them. For example, it states that governments must "consult the peoples concerned . . . whenever consideration is being given to legislative or administrative measures which may affect them directly" and must "establish means by which these peoples can freely participate, to at least the same extent as other sectors of the population, at all levels of decision-making in elective institutions and administrative and other bodies responsible for policies and programmes which concern them." 150

The international community has put special emphasis on the right to participate in policy making with environmental consequences. For example, Principle 10 of the Rio Declaration on Environment and Development states that:

Environmental issues are best handled with the participation of all concerned citizens, at the relevant level. At the national level, each individual shall have appropriate access to information concerning the environment that is held by public authorities, including information on hazardous materials and activities in their communities, and the opportunity to participate in decision-

143. Universal Declaration of Human Rights, supra note 57, art. 21.

144. Id.

145. International Covenant on Civil and Political Rights, supra note 57, art. 25.

146. Human Rights Comm., General Comment No. 25, The Right to Participate in Public Affairs, Voting Rights and the Right of Equal Access to Public Service, If 2, U.N. Doc. CCPR/C/21/Rev.1/Add.7 (July 12, 1996).

147. Id. 15 .

148. American Convention on Human Rights, supra note 97, art. 23.

149. African [Banjul] Charter on Human and Peoples' Rights, supra note 120, art. 13.

150. International Labour Organization Indigenous and Tribal Peoples Convention (No. 169) art. 6, adopted June 27, 1989, 28 I.L.M. 1382. The convention grants peoples the right to participate in policy making that may affect them directly. Id. art. 7. Indigenous peoples are to have access to legal proceedings for the protection of their rights. $I d$. art. 12. Also, the treaty states that a primary goal of education of indigenous children is to help them participate in both their own and national communities. Id. art. 29. 
making processes. States shall facilitate and encourage public awareness and participation by making information widely available. Effective access to judicial and administrative proceedings, including redress and remedy, shall be provided. ${ }^{151}$

The United Nations Environment Programme developed draft guidelines for the implementation of Principle 10 in 2010. These guidelines provide that states must ensure that members of the public, including both individuals and NGOs, have the opportunity to participate meaningfully in environmental decision making and be informed of this opportunity. ${ }^{152}$ The United Nations Economic Commission for Europe's Convention on Access to Information, Public Participation in Decisionmaking and Access to Justice in Environmental Matters, commonly known as the Aarhus Convention, contains many similar provisions. ${ }^{153}$ Although the guidelines and the convention are limited to environmental decision-making processes, they are significant because they enshrine the right of both individuals and NGOs to seek to influence policy making and to access and use courts to vindicate their rights.

Although these instruments usually, although not exclusively, refer to participation in national policy making, the point is that individuals have a right to take part in the formulation and implementation of policies that affect them. If states were truly representative, perhaps it would be unnecessary to give effect to such a right at the international level. States would represent their people, and there would be no need for "interference" by nonstate actors, except perhaps for transnational constituencies. Yet because many states are unrepresentative, undemocratic, or captured by powerful elites, individuals and other nonstate actors frequently have no ability to influence policy making or administration taking place in international courts, even if it impacts their interests directly. The failure to include individuals who are affected threatens international courts' legitimacy. It excludes from the purview of policymakers or administrators the voices of those whose lives may be most deeply altered by the policies they craft.

\section{b. International courts and the conduct of public affairs}

Participation in the conduct of public affairs is generally understood in relation to the exercise of political power and administration. ${ }^{154}$ This Part proposes that the activities of international courts, at least some of the time, fall within these categories.

151. United Nations Conference on Environment and Development, Rio de Janeiro, Braz., June 3-14, 1992, Rio Declaration on Environment and Development, U.N. Doc. A/CONF.151/26/Rev.1 (Vol. I), Annex I (Aug. 12, 1992).

152. Governing Council of the U.N. Env't Programme, Guidelines for the Development of National Legislation on Access to Information, Guideline 8, adopted by the Governing Council in decision SS.XI/5, part A (Feb 26, 2010).

153. Convention on Access to Information, Public Participation in Decision-making and Access to Justice in Environmental Matters arts. 1, 3, 9, June 25, 1998, 2161 U.N.T.S. 447 (forty-five parties as of May 15, 2012).

154. See The Right to Participate in Public Affairs, Voting Rights and the Right of Equal Access to Public Service, supra note 146, 125 (providing for "the free communication of information and ideas about public and political issues between citizens, candidates and elected representatives is essential" to enjoy freedom to engage in political activity). 
Further, international courts are generally not embedded in a constitutional system of checks and balances, so participation by those most affected is a meaningful way of justifying their authority.

International courts' power frequently extends beyond merely deciding a one-time dispute. They are part of the architecture of global governance. An international court or tribunal is not a legislature at the international level. Yet international courts are engaged in law making. And the activities of some international courts, at least some of the time, have been characterized as regulatory or administrative in nature. Nico Krisch and Benedict Kingsbury define global administrative bodies as those engaged in administrative and regulatory functions, or "the setting and application of rules by bodies that are not legislative or primarily adjudicative in character."155 They propose that WTO dispute resolution can, in many cases, be regarded as "another layer of judicial review of domestic administrative action" and as part of a widely variegated "global administrative space."156 J.H.H. Weiler, too, notes the emergence of a "regulatory layer" in the international legal system and situates activities of the WTO within it. ${ }^{157}$ Similarly, Gus Van Harten and Martin Loughlin argue that investment treaty arbitration constitutes "a powerful species of global administrative law" because its norms and mechanisms "exert a strong disciplinary influence over domestic administrative programmes." 158

Global administrative law applies administrative law principles to bodies engaged in administration, including international courts. It arises from the idea that global governance is a form of administration and that administration can be influenced by administrative law principles. ${ }^{159}$ These include principles derived from democratic theory, like procedural participation, transparency, and reasoned decisions. ${ }^{160}$ To the extent that these bodies are a part of a global-administrative or policy-making space rather than a traditional dispute-settlement mechanism, it is fitting to apply global

155. Nico Krisch \& Benedict Kingsbury, Introduction: Global Governance and Global Administrative Law in the International Legal Order, 17 EUR. J. INT'L L. 1, 3 (2006).

156. Id.; see also G. Richard Shell, Trade Legalism and International Relations Theory: An Analysis of the World Trade Organization, 44 DUKE L.J. 829, 914 (1995) (asserting that the WTO acts as a regulatory agency that formulates and adjusts trade policy among large democratic states).

157. Weiler, supra note 135, at 549-50.

158. Gus Van Harten \& Martin Loughlin, Investment Treaty Arbitration as a Species of Global Administrative Law, 17 Euro. J. INT'L L. 121, 122 (2006); see also David Livshiz, Note, Public Participation in Disputes Under Regional Trade Agreements: How Much Is Too Much-The Case for a Limited Right of Intervention, 61 N.Y.U. ANN. SURV. AM. L. 529, 532-33 (2005) (characterizing the activities of dispute settlement institutions provided by regional trade agreements as "analogous to that of a traditional administrative agency"); Jason Webb Yackee, Controlling the International Investment Law Agency, 53 HARV. INT'L L.J. 391, 394 (2012) (analogizing the international investment law to an administrative agency).

159. Krisch \& Kingsbury, supra note 155 , at 3.

160. See, e.g., Benedict Kingsbury et al., The Emergence of Global Administrative Law, 68 LAw \& CONTEMP. PROBS. 15, 37-39 (2005) (highlighting the procedural participation, transparency, and reasoned administrative decisions reflected in global administrative practice); Krisch \& Kingsbury, supra note 155, at 4 (stating that transparency, participation, and review are emerging as mechanisms in global regulatory decision making). But see Carol Harlow, Global Administrative Law: The Quest for Principles and Values, 17 EUR. J. INT'L L. 187, 187, 213 (2006) (arguing that such principles are based mainly in Western legal approaches and are leading to an undesirable "juridification" of political processes). 
administrative law principles, which often reflect democratic ones, to them. ${ }^{161}$

Furthermore, whether engaged in administration or law making, international courts are much more difficult to hold accountable than domestic ones. The concern that domestic legal scholars raise about the countermajoritarian difficulty ${ }^{162}$ is exacerbated at the international level. The difference is that international courts already make decisions that legislatures would at the domestic level. Armin von Bogdandy and Ingo Venzke call this phenomenon the "decoupling of law from parliamentary politics." 163 And often there is no legislature at all to counteract the activities of international courts, as they are rarely embedded in a constitutional framework of checks and balances. ${ }^{164}$ While states may, in some cases, withdraw from an international court's jurisdiction or refuse to implement its decisions if they are not directly enforceable, other international actors may have no way of influencing the decision-making process unless a litigant in a case adopts their views. The case for democratic controls, including enhanced participation, is much stronger at the international level than at the domestic one.

\section{c. Who gets to participate and can enhanced participation be antidemocratic?}

One of the challenges of applying democratic theory to the international legal system is determining who the demos is. ${ }^{165}$ Is it states, peoples, individuals, women, indigenous persons, or corporations? To whom are international courts supposed to be accountable? In short, who gets to participate? The democratic principle at issue here is that those whose interests are affected by the decisions of international courts should have some ability to participate in their processes. ${ }^{166}$ In other words, the demos is the diverse set of beneficiaries of international court decision making. The demos can also be called stakeholders. Stakeholders must have some meaningful interest in the direction that the law may take in a particular dispute. The law at issue must be relevant to the conduct of public affairs; it must transcend the boundaries of the dispute before the court and have some broader impact beyond the litigating parties. In this vein, some courts and tribunals have already limited the use of amicus briefs to disputes

161. See Krisch \& Kingsbury, supra note 155 , at 4 (stating that "building mechanisms analogous to domestic administrative law systems" has become a trend in the area of global governance).

162. See Jeremy Waldron, The Core of the Case Against Judicial Review, 115 YALE L.J. 1346, 1348-50 (2006) (analyzing the "counter-majoritarian difficulty" countries face when allowing courts to invalidate legislation).

163. von Bogdandy \& Venzke, supra note 14 , at 993.

164. See id. at 993-95 (finding that the "main avenue of democratic legitimation"-the separation of powers-is strained in the international context).

165. See Besson, supra note 137 , at 68 (stating that no set criteria exists for establishing whether a multitude of people is a demos or a political community); Nico Krisch, The Pluralism of Global Administrative Law, 17 EUR. J. INT'L L. 247, 247 (2006) (noting the problem of determining to whom global governance should be accountable); Weiler, supra note 135, at 560 (discussing the difficulty of determining who the demos is in a democracy).

166. See Besson, supra note 137, at 66 (proposing that democracy mandates that those whose interests are affected by policies are able to participate in the process that makes those policies); De Búrca, supra note 135 , at 276-77 (asserting that participation by all interested individuals is an essential element of the "democratic-striving" approach). 
concerning the "public interest" alone. ${ }^{167}$

The counterargument from a democratic theory standpoint is that opening up the international courthouse doors to expanded participation will not enhance the democratic legitimacy of the decisions of international courts. ${ }^{168}$ Those with the means and motive to make their voices heard, including NGOs and corporations, may not have spotless democratic credentials. Further, those who speak the most or the loudest may not represent the majority of the world. ${ }^{169}$ Finally, the state, where numerous interests must compete and compromise with each other, is the right place for these kinds of discussions, not international courts. ${ }^{170}$ States represent the relevant stakeholders.

International courts can institutionalize safeguards to address these concerns. They can adopt approaches to limit the type of stakeholder who gets to participate. For example, courts could mandate that nonlitigants apply for some kind of consultative status or preauthorization before a particular dispute resolution system. In Measures Affecting Asbestos and Asbestos-Containing Products, the WTO Appellate Body required nondisputing, nonstate actors wishing to file amicus briefs to make a number of showings, including that their contributions would help to resolve the pending dispute in accordance with WTO law and would not duplicate arguments of parties or third parties to the dispute. ${ }^{171}$ Similarly, the ICSID Arbitration Rules grant tribunals the authority to allow nondisputing parties to file written submissions after consultation with the parties to the dispute, so long as the submission addresses a matter within the scope of the dispute. ${ }^{172}$ The rules also consider whether the submission "would assist the Tribunal in the determination of a factual or legal issue related to the proceeding by bringing a perspective, particular knowledge or insight that is different from that of the disputing parties," and whether the nondisputing party has "a significant interest in the proceeding." 173

167. Eric De Brabandere, NGOs and the "Public Interest": The Legality and Rationale of Amicus Curiae Interventions in International Economic and Investment Disputes, 12 CHI. J. INT'L L. 85, 102-03 (2011).

168. See, e.g., Trachtman \& Moremen, supra note 2, at 227-28 (questioning the democratic credentials of nonstate actors such as NGOs and corporations).

169. For example, Egypt argued that allowing amicus briefs at the WTO would give NGOs in developed countries more of a voice than those from the developing world because the former have greater access to resources and time. Appellate Body Meeting Minutes, Communication from the Appellate Body to the Chairman of the Dispute Settlement Body on Europoean Communities - Measures Affecting Asbestos and Asbestos-Containing Products, ๆ 21, WT/GC/M/60, (Jan. 23, 2001).

170. See Trachtman \& Moremen, supra note 2, at $227-28$ (arguing that permitting private participants to engage in WTO dispute settlement does not enhance the legitimacy of the process because the "unidimensional" perspectives and interests of private participants are not on par with the multifaceted interests of the states that currently participate in WTO dispute settlement).

171. Appellate Body Communication, European Communities - Measures Affecting Asbestos and Asbestos-Containing Products, ๆ 3(f), WT/DS135/9 (Nov. 8, 2000).

172. ICSID Rules of Procedure for Arbitration Proceedings, Rule 37(2), available at https://icsid.worldbank.org/ICSID/StaticFiles/basicdoc/partF-chap04.htm\#r37.

173. Id. The tribunal also has the responsibility of ensuring, through consultation with the disputing parties, that the submission of the nondisputing party "does not disrupt the proceeding or unduly burden or unfairly prejudice either party." $I d$. 
Alternatively, if these safeguards are deemed insufficient by a particular dispute resolution body, states could establish standards by which to judge the democratic credentials of these groups. Another approach is for states and stakeholders to create a list of broad categories that nonlitigants are allowed to address, like impact on the environment, human rights, or economic growth, and force various groups to collaborate on a single brief to address each broad issue. Finally, courts could themselves ask nonlitigants whose views they believe are relevant and unrepresented to make a submission.

Arguing that the place for democratic dialogue is at the domestic level is easy when one comes from a democratic state. Yet many potential participants do not. Even when they do, the state may have ignored the views of a particular group in its internal decision-making process. A group may be traditionally discriminated against by the state, as indigenous people frequently are, or it may be transnational and possess little gravitas within the borders of any one state. One could attempt to force democratic contestation to take place at the domestic level by requiring states to submit their litigation strategy ideas to the public for comment, as at least one free trade agreement did. ${ }^{174}$ Nonetheless, if a state systematically discriminates, or if a transnational group is involved, true democratic contestation is unlikely to take place. In other words, the international court may be the only place where a multitude of interested voices is heard.

\section{d. What does participation in the conduct of public affairs look like?}

The right to participate in the conduct of public affairs requires some commitment to transparency. Pleadings and hearings must be open and accessible for nonlitigants to determine whether they have interests at issue and whether they have something unique and worthwhile to contribute to the discussion. Some courts' official languages are not in the language - or even the common language-of the litigating parties, making it very difficult for stakeholders to comment on what the court is doing, or even on their own state's behavior in the proceedings. Similarly, simultaneous transcription or televised hearings should be the norm for international courts located across the world from where their rulings will be felt.

What should the involvement of the public look like? Different courts may adopt different methods. One option is to allow stakeholders to file amicus briefs. Even if their rights are not directly at issue, stakeholders should have the opportunity to present relevant points as the court makes decisions that will shape the law prospectively. Again, especially when states are unrepresentative, amicus participation is perhaps the only formal way that nonstate actors and nonlitigants can influence policy making taking place in international courts. If an overwhelming number of groups or individuals seek to file amicus briefs, courts can develop methods by which to screen and filter the number of briefs, including establishing in which areas they wish to hear contributions and ensuring that submissions are not duplicative.

Several tribunals have already moved in the direction of allowing amicus participation for nonstate actors. For example, human rights courts such as the ECHR

174. United States-Singapore Free Trade Agreement Implementation Act, Pub. L. No. 108-78, 117 Stat. 948 (2003). 
and the Inter-American Court of Human Rights typically accept amicus briefs. ${ }^{175}$ Nonetheless, although the WTO and international investment tribunals increasingly permit the use of amicus briefs as a policy matter, ${ }^{176}$ Eric De Brabandere points out that "there has not yet been substantial effective acceptance or consideration of such submissions in particular cases." 177 Other international courts, including the ICJ, do not allow for amicus participation at all in contentious cases. ${ }^{178}$

Another approach is to create a new position in the secretariats of these various international courts to advise them on the impact of their decision making on nondisputing parties. This person could present the court or tribunal with information about the potential impact of its decisions on nonlitigants whose interests are implicated in the case. Stakeholders could share their concerns and arguments with this person who would present them to the tribunal. Such an advisor would have to possess excellent credentials and credibility and the ability to absorb and condense information gleaned from a number of sources.

Regardless of whether an institutional advisor or amicus briefs are used, adjudicators must be open to the arguments of nonlitigants for their participation to be meaningful. They must not prize the interests of the litigating parties over those of other nonlitigating parties, so long as the nonlitigating parties make arguments relevant to determination of the underlying dispute. This may require input from nonstate actors in the appointment of judges and arbitrators. Finally, adjudicators must consider the views of nonlitigants in their decision making to the extent that they matter for resolution of the underlying dispute.

As nonstate actors are increasingly recognized as holders of rights and duties under international law, their exclusion from processes that adjudicate their

175. Convention for the Protection of Human Rights and Fundamental Freedoms, supra note 24, art. 36(2) (providing that "[ $t]$ he President of the Court may, in the interest of the proper administration of justice, invite any High Contracting Party which is not a party to the proceedings or any person concerned who is not the applicant to submit written comments or take part in hearings"); Rules of Procedure of the Inter-American Court of Human Rights, art. 44, approved by the court during its 85 th regular period of sessions, held from Nov. 16-28, 2009, available at http://www.corteidh.or.cr/sitios/reglamento/nov_2009_ing.pdf.

176. Although the WTO Dispute Settlement Understanding does not provide for amicus participation, the Appellate Body ruled in the United States-Shrimp and United States-Lead and Bismuth II cases that WTO panels and the Appellate Body have the power to accept amicus briefs. See Appellate Body Report, United States - Import Prohibition of Certain Shrimp and Shrimp Products, 9 91, WT/DS58/AB/RW (Oct. 22 2001) (admitting amicus briefs attached to the United States' submission); Appellate Body Report, United States Imposition of Countervailing Duties on Certain Hot-Rolled Lead and Bismuth Carbon Steel Products Originating in the United Kingdom, \39, WT/DS138/AB/R (May 10, 2000) (finding that the WTO Appellate Body has "the legal authority to decide whether or not to accept and consider any information that we believe is pertinent"). Similarly, the ICSID Arbitration Rules now too allow for submissions by nondisputing parties, upon consultation with the litigating parties. ISCID Convention Regulations \& Rules, Arbitration Rule 37(2), Apr. 2006, available at http://icsid.worldbank.org/ICSID/StaticFiles/basicdoc/CRR_English-final.pdf; see also Methanex Corp v. United States, Decision of Tribunal on Petitions from Third Persons to Intervene as Amici Curaie, qा 47, 53 (Jan. 1, 2001 NAFTA/UNCITRAL) (stating that NAFTA tribunals have the power to accept amicus curiae submissions).

177. De Brabandere, supra note 167 , at 87.

178. See ICJ Statute, supra note 22 (containing no provisions on amicus submissions by nonstate actors); Shabtai Rosenne, 2 The LaW and PRACTiCe of THE INTERnational COURT, 1920-1996, at 653-54 (3d ed. 1997) (stating that ICJ practice "does not envisage" the presentation of arguments by nonstate actors). 
entitlements and shape their interests threatens to undermine the authority of international courts and tribunals. It becomes difficult to justify international courts' authority when extended over persons who lack the ability to participate or sometimes even to access judicial proceedings that adjudicate their international legal rights and obligations or shape public policy. Legitimacy requires a reimagining of procedural faimess to account for both rights holders and stakeholders.

\section{B. What About Justice (or Substantive Legitimacy)?}

Many have shied away from justice as important to legitimacy in the international arena. Fewer still have explicitly applied such a lens to international courts. This Part argues that substantive justice can and should be an important part of legitimacy for international courts.

Most scholars have steered away from justice in the legitimacy debate for a number of reasons. Allen Buchanan and David Golove propose that legal realists, who view international relations as a Hobbesian state of nature, and legal nihilists, who contend that international law is not law, have traditionally dominated the field of international legal philosophy and see no place for moral theorizing. ${ }^{179}$ Thomas Franck hesitated to probe the linkages between justice and legitimacy for both "operational" and "theoretical" reasons. ${ }^{180}$ Operationally, justice can only be done to people, not entities like states, and international law primarily addresses states, not individuals, making it quite complicated to discern workable principles of justice. ${ }^{181}$ For example, John Rawls's suggestion of putting foreign ministers behind a "veil of ignorance" to discern principles of justice would result in rules that favor states' interests over those of individuals. ${ }^{182}$ Foreign ministers would likely arrive at a rule of nonintervention, which would allow for genocide, and therefore cannot be just. ${ }^{183}$ Second, from a theoretical perspective, distinguishing between justice and legitimacy allows for the development of principles that acknowledge and accommodate the existence of different moral communities, while postponing debate on the meaning of justice. ${ }^{184}$ Despite his discomfort with engaging in the justice debate, Franck simultaneously embraced the centrality of justice: "[a]s the firm outlines of world order become readily apparent, and as that order increasingly focuses on the individual's place in global society, a keener understanding of the theory, function, and power of justice must surely move to the top of the agenda."185

Franck's operationalization critique is less powerful than it used to be. First, intemational law is increasingly recognized to address the rights and duties of actors

179. Allen Buchanan \& David Golove, Philosophy of International Law, in THE OXFORD HANDBOOK OF JURISPRUDENCE AND PHILOSOPHY OF LAW 871, 872-73 (Jules Coleman \& Scott Shapiro eds., 2002); see also Caron, supra note 5, at 514 (stating that "[i]n general, critiques of legitimacy-at least in legal scholarshipoften are directed to procedural rather than substantive legitimacy").

180. ThOMAS M. FranCK, The POWER OF LegitimaCy AMONG Nations 208-09 (1990).

181. Id.

182. Id. at 218-21 (citing JOHN RAWLS, A THEORY OF JUSTICE 7 (1971)).

183. Id. at 221 .

184. Id. at 236.

185. Id. at 246. 
beyond states, especially natural persons. While it may be primarily aimed at states, international law contains much about the rights and duties of human beings, without whom states would not exist in the first place. It may be challenging to discern workable principles of justice for a multifarious world of international actors, but the pursuit of justice remains an important objective of international law. ${ }^{186}$ Second, by excluding all international actors except states, one limits the capacity to think creatively and deeply about both justice and legitimacy.

As for the theoretical critique, Franck's "firm outlines of world order" are more apparent. ${ }^{187}$ While discerning a common standard of justice in a world of seven billion people, states, corporations, and international organizations is a daunting challenge, a growing consensus exists that justice requires, at a minimum, some recognition of the freedom and equality of human beings. ${ }^{188}$ As explained below, the international community, through treaties and other sources of international law, has deemed violations of some human rights so egregious that it forbids their commission under any circumstances. It has reached some agreement on justice, or rather injustice. So long as international courts help states to better respect these substantive legal obligations than they would on their own, Joseph Raz's service conception of authority links justice and legitimacy. ${ }^{189}$ Further, courts cannot condone or facilitate the violation of a minimum core set of human rights and remain legitimate.

\section{A Minimum Core Set of Human Rights}

The international community agrees that some core set of human rights exists that should not be violated in any circumstance. Both global and regional treaties prohibit derogation from a limited subset of rights even during public emergency or war. For example, the ICCPR, regardless of the existence of a public emergency, forbids states from derogating from (1) rights to life, freedom from torture, and freedom from slavery; (2) freedom from imprisonment for failure to fulfill a contractual obligation; (3) freedom from the application of ex post facto laws in criminal trials; (4) recognition as a person before the law; and (5) freedom of thought, conscience and religion. ${ }^{190}$ The Convention Against Torture, too, declares that "[n]o exceptional circumstances whatsoever, whether a state of war or a threat of war, internal political instability or any

186. See Mortimer Sellers, Parochialism, Cosmopolitanism, and Justice, in Parochialism, COSMOPOLITANISM, AND THE FOUNDATIONS OF INTERNATIONAL LAW, supra note 13, at 250, 259 (stating that the "purpose of law and the international community is justice," as recognized by the United Nations Charter); Marti Koskenniemi, Book Review, 86 AM. J. INT'L L. 175, 178 (1992) (discussing the "essential continuity and embeddedness" of law and justice); W. Michael Reisman, Theory About Law: Jurisprudence for a Free Society, 108 YALE L.J. 935, 939 (1999) (describing Myres McDougal and the New Haven School's jurisprudential "insistence that the end of law and the criterion for appraisal of particular decisions was their degree of contribution to the achievement of a public order of human dignity").

187. FRANCK, supra note 180 , at 246.

188. See TESÓN, supra note 104, at 1 (arguing that "the end of international law must ... be to benefit, serve, and protect human being"); Buchanan \& Golove, supra note 179, at 876-77 (explaining that the expanding global culture of human rights reflects a conception of justice based on "the recognition of the equality and freedom of all persons").

189. See infra Part III.B.2 for an analysis of Raz's service conception of authority.

190. International Covenant on Civil and Political Rights, supra note 57, arts. 4, 6, 7, 11, 15, 18. 
other public emergency, may be invoked as a justification of torture."191 Similarly, the Genocide Convention declares that states must commit themselves to prevent and punish genocide, "whether committed in time of peace or in time of war."192

The American Convention on Human Rights provides that states may not suspend the rights to juridical personality, life, humane treatment (freedom from torture), freedom from slavery, freedom from ex post facto laws, freedom of conscience and religion, rights of the family, right to a name, rights of the child, right to nationality, right to participate in government, or of judicial guarantees essential for the protection of such rights. ${ }^{193}$ The European Convention for the Protection of Human Rights and Fundamental Freedoms establishes that no derogation is permitted during a time of emergency from the rights to life (unless from lawful acts of war), freedom from torture, freedom from slavery, and freedom from ex post facto laws. ${ }^{194}$ The African Charter on Human and Peoples' Rights does not contain a nonderogation clause. ${ }^{195}$ But the African Commission on Human and Peoples' Rights has already declared Articles 7 (fair trial rights, no application of ex post facto laws), 2 (non-discrimination), and 3 (equal protection) as nonderogable even in times of emergency, ${ }^{196}$ and it may recognize more in the future. ${ }^{197}$

The Rome Statute of the International Criminal Court provides compelling evidence of consensus that a minimum core of human rights guarantees exists that should not be violated. Specifically, by describing "the most serious crimes of concern to the international community as a whole," including genocide, war crimes, and crimes against humanity, the Rome Statute establishes that some violations of human rights are so egregious that the international community will condemn and prosecute them at the international level. ${ }^{198}$ Further, the Rome Statute limits the court to application and interpretation of applicable law that is "consistent with internationally recognized human rights." 199 That is, in the Rome Statute, the international community recognizes that some human rights have the power to trump all other applicable sources of law in the International Criminal Court.

191. Convention Against Torture and Other Cruel, Inhuman or Degrading Treatment or Punishment, supra note 57 , art. 2(2).

192. Convention on the Prevention and Punishment of the Crime of Genocide art. 1, Dec. 9, 1948, 78 U.N.T.S. 277.

193. American Convention on Human Rights, supra note 97 , art. 27(2).

194. ECHR, supra note 24 , arts. 2, 3, 4, 7, 15 .

195. African [Banjul] Charter on Human and Peoples' Rights, supra note 120; see also U.O. Umozurike, The African Charter on Human and Peoples' Rights, 77 AM. J. INT'L L. 902, 909-10 (1983) (discussing the lack of a nonderogation clause in the African Charter on Human and Peoples' Rights).

196. Purohit \& Moore v. Gambia, Afr. Comm'n on Human \& Peoples' Rights., Commc'n No. 241/2001, If 49 (2003), available at http://wwwl.umn.edu/humanrts/africa/comcases/241-2001.html (discussing Articles 2 and 3); Civil Liberties Organisation, Legal Defence Centre, Legal Defence \& Assistance Project v. Nigeria, Afr. Comm'n Human \& Peoples' Rights, Commc'n No. 218/98, I 27 (1998), available at http://www l.umn.edu/humanrts/africa/comcases/218-98.html (discussing Article 7).

197. Adeno Addis, Book Review, 98 AM. J. INT'L L. 879, 881-82 (2004) (arguing that Article 60 of the African Charter on Human and Peoples' Rights provides the African Commission on Human and Peoples' Rights with the authority to invoke the ICCPR and declare provisions nonderogable).

198. Rome Statute of the International Criminal Court art. 5, July 17, 1998, 2187 U.N.T.S. 90.

199. Id. art. 21. 
Further, the international community has recognized the existence of jus cogens, or peremptory norms that supersede all other sources of legal obligation, as well as erga omnes obligations, or duties that states owe to all other states. ${ }^{200}$ The debate continues on what qualifies as a peremptory norm, but the usual suspects include the prohibitions against genocide, slavery, torture, and racial discrimination. ${ }^{201}$ These appear to coincide with the nonderogation provisions of the ICCPR, the European Convention, the American Convention, and potentially the African Charter, the Genocide and Torture Conventions, and conduct deemed criminal by the Rome Statute. ${ }^{202}$

Publicists, too, have sought to enumerate which rights fall within this category. ${ }^{203}$ For example, Allen Buchanan and Robert $O$. Keohane suggest that the agreed-upon core includes rights to physical security, freedom from slavery, servitude and forced occupations, and the right to subsistence. ${ }^{204}$ Similarly, David Miller argues that the international community has a responsibility to protect "basic rights" like "rights to life, bodily integrity, basic nutrition and health, and so forth."205

Listing core rights is somewhat controversial and requires greater consensus. ${ }^{206}$ For example, feminist scholars assert that political rights are generally overemphasized and obviate economic, social, and cultural rights that affect women's lives more deeply. ${ }^{207}$ Third world critiques, too, question the traditional western rights literature as leaving out the fundamental concerns of much of the world. ${ }^{208}$ Further, one can imagine linking justice to an act's impact on the environment or on the equitable distribution of resources among different peoples. ${ }^{209}$ Finally, the set of core rights may change over time and may be of greater scope in some regions of the world than

200. See Vienna Convention on the Law of Treaties arts. 53, 64, opened for signature May 23, 1969, 1155 U.N.T.S. 331 (stating that all treaties that conflict with peremptory norms are void); Barcelona Traction, Light and Power Company, Limited (Belg. v. Spain), 1970 I.C.J. 3, ๆ 33 (Feb. 5) (declaring that states have obligations to the international community as a whole).

201. Erika de Wet, The Emergence of International and Regional Value Systems as a Manifestation of the Emerging International Constitutional Order, 19 LEIDEN J. INT'L L. 611, 616 (2006).

202. See supra notes 200-208 for a discussion of the provisions contained within these various charters, conventions, and statutes. Customary international law can also provide a source for these prohibitions but is not discussed in this Article.

203. Although their teachings do not constitute a formal source of international law, they can be used as a "subsidiary means" for the determination of rules of international law. ICJ Statute, supra note 22, art. 38.

204. Buchanan \& Keohane, supra note 7, at 420.

205. David Miller, The Responsibility to Protect Human Rights, in LeGITIMACY, Justice AND PUBliC INTERNATIONAL LAW, supra note 13, at 232, 232.

206. Buchanan \& Keohane, supra note 7 , at 420 (acknowledging that disagreement exists as to the content of core rights).

207. Hilary Charlesworth et al., Feminist Approaches to International Law, 85 AM. J. INT'L L. 613, 634 $36(1991)$.

208. E.g., Makau Mutua, Human Rights and Powerlessness: Pathologies of Choice and Substance, 56 BUFF. L. REV. 1027, 1027-28 (2008).

209. See Daniel Butt, 'Victors' Justice'? Historic Injustice and the Legitimacy of International Law, in Legitimacy, Justice AND PUblic INTERnational LAW, supra note 13, at 163, 164 (arguing that existing international law reinforces and preserves unjust resource distribution among states); Alan Boyle, Human Rights or Environmental Rights? A Reassessment, 18 FORDHAM ENVTL. L. REV. 471, 472 (2007) (discussing the relationship between environmental and human rights). 
others. ${ }^{210}$ Yet although serious debate exists on the limits of core rights, it is difficult to deny that some minimum agreed-upon set exists. ${ }^{211}$ At a bare minimum, this list appears to include the prohibitions against genocide, torture, racial discrimination, and slavery.

\section{Linking the Core Rights to Legitimacy and Counterarguments}

What is the link between violation of a core set of human rights by states and the legitimacy of international courts? This Part provides two answers and seeks to respond to some counterarguments. The first answer relies on Raz's service conception of authority. The second argues that international courts that facilitate or tacitly assent to conduct that the international community as a whole condemns are illegitimate.

Raz's service conception of authority, the preeminent instrumentalist approach, posits that an authority is justified when (1) it takes into account reasons that independently apply to the subjects of its directives and are relevant in the circumstances ("dependence thesis"), and (2) the subjects are more likely to comply with reasons that apply to them independently by accepting and implementing the authority's directives than by attempting to follow these reasons on their own ("normal justification thesis"). ${ }^{212}$ In other words, an authority is justified when its subjects do a better job of complying with their obligations by doing what the authority says than they would in the authority's absence. ${ }^{213}$

International law prohibits states from violating some core set of human rights guarantees, no matter what the circumstances. They cannot commit genocide, enslave, torture, or engage in racial discrimination. Consequently, an international court's authority is justified when it helps states comply with these prohibitions and when it takes these prohibitions into account when issuing its decisions. International courts can help states to better comply with these requirements because they bring disputes from the war room to the courtroom, force state decision makers to view their actions through the lens of international law rather than politics, and likely raise the costs of noncompliance through judicial judgments and orders. International courts would lack legitimacy if states did no better at complying with these human rights guarantees in their absence.

Another argument for the link between injustice and illegitimacy is that international courts lack the authority to condone or facilitate state conduct that violates these prohibitions. International courts are established by states to apply international law. They cannot act in a manner that facilitates the violation of international law, especially norms the international community deems of such high stature. To do so

210. de Wet, supra note 201 , at 612-13.

211. See John Tasioulas, The Legitimacy of International Law, in THE PHILOSOPHY OF INTERNATIONAL LAW, supra note 99, at 97, 107 (asserting that scholars' rejection of ethical objectivity is "deeply problematic" because it "forecloses on the possibility of radical, non-question-begging criticism of social practices, no matter how seemingly wicked").

212. RAZ, supra note 13 , at 47,53 . In recent years, a number of international law scholars have examined Joseph Raz's scholarship in the context of the legitimacy of international law. E.g., Meyer \& Sanklecha, supra note 13, at 5-8; Tasioulas, supra note 211, at 100-11.

213. The "pre-emption thesis" adds that a legitimate authority's orders provide a reason for action that supersedes some independent reasons. RAZ, supra note 13, at 46-47; Meyer \& Sanklecha, supra note 13, at 6. 
would exceed the scope of authority delegated to them.

But doesn't considering whether a state's behavior violates core human rights run contrary to the object and purpose of many of these courts (at least the non-humanrights ones)? Why should the WTO's Appellate Body and ICSID think about human rights when they were established to liberalize trade and promote foreign investment? An international court would act beyond the scope of its delegated authority by considering issues not raised by the litigating parties. Requiring international courts of all kinds to consider the fundamental human rights implications of their decisions is a distraction from the primary mission of international courts as dispute settlers.

Considering whether state action would violate a core set of human rights guarantees does not run contrary to the object and purpose of international adjudication but rather is consistent with it. The various regimes that an international court may address can be considered "mutually supportive." 214 The idea is that all international rules are part of the same legal system and should be understood as "reinforcing each other with a view to fostering harmonization and complementarity, as opposed to conflictual relationships." 215 None of these courts exist in "clinical isolation" from the rest of public international law, including human rights law. ${ }^{216}$ The duty not to violate basic human rights is part of the world of law from which they draw, even if the case at issue concerns trade law, the law of the sea, or expropriation. ${ }^{217}$ Simply, there are some lines that international courts cannot cross and still retain their legitimacy. ${ }^{218}$

Further, mandating that states comply with a core set of human rights norms is not like the application of an ex post facto law. States themselves agreed to be bound by a core set of human rights requirements through wide ratification of human rights treaties and by virtue of customary international law and jus cogens norms. They have been on notice for many years that these are part of their international legal obligations.

Not only do morality and law require states to act consistent with these human rights guarantees, but also mandating that courts consider whether state action will violate these rights will strengthen the normative power and appeal of all of their decisions. By ignoring states' legal obligations with respect to core human rights,

214. Riccardo Pavoni, Mutual Supportiveness as a Principle of Interpretation and Law-Making: A Watershed for the 'WTO-and-Competing-Regimes' Debate?, 21 EUR. J. INT'L L. 649, 650 (2010).

215. Id. at 650.

216. Appellate Body Report, United States - Standards for Reformulated and Conventional Gasoline, 17, WT/DS2/AB/R (Apr. 29, 1996); see also Fragmentation of International Law, supra note 133, If 45 (referring to the WTO's decision not to read the General Agreement on Tariffs and Trade in isolation from the rest of international law).

217. See Joost Pauwelyn, The Role of Public International Law in the WTO: How Far Can We Go?, 95 AM. J. INT'L L. 535, 539 (2001) (discussing the interrelation of trade law and the international legal system).

218. See KLABBERS ET AL., supra note 15, at 152 (arguing that the decisions of international courts that violate international human rights should not be respected by national courts). Fernando Tesón proposes that:

All exercise of power must be morally legitimate. Roughly, an exercise of power is morally legitimate when it is the result of political consent and respects the basic rights of the individuals subject to that power. If international law is to be morally legitimate, therefore, it must mandate that states respect human rights as a precondition for joining the international community.

TESON, supra note 104, at 2. This argument is similar to Allen Buchanan and Robert O. Keohane's argument that global governance institutions must meet some minimum level of moral acceptability for legitimacy. Buchanan \& Keohane, supra note 7, at 419-422. 
courts risk undermining their own power in other cases. Imagine if a court denied a provisional measures request because it found that state sovereignty trumped an ongoing genocide. The taint of the court's decision is likely to spill over into other cases and to undermine the court's objectives. ${ }^{219}$ Is there any way to justify the authority of such a court?

\section{Institutional Reforms}

Then what institutional reforms can be made to promote justice? First, states and others should engage in an ongoing discussion to determine which additional violations of basic human rights they will not permit international courts to condone. ${ }^{220}$ These rights may vary by region or by the subject matter jurisdiction of a particular court. For example, parties and stakeholders at ICSID may arrive at a different list than the ICJ. The emergence of different standards in different courts is not necessarily a cause for concern so long as the bare minimum is respected. Second, courts must consider the implications of their decisions on the core set of fundamental human rights in each decision they make. Third, they must determine whether a conflict exists between the core set of individual rights and the other competing rights and obligations at issue in the case. Fourth, if a conflict exists, the court must hold these core individual rights above any other rights and obligations involved in the case. Courts must help states better to comply with core human rights requirements than states would in their absence, and international courts cannot cross certain substantive lines and still maintain their legitimacy, regardless of competing rights. This approach to legitimacy ultimately establishes a normative hierarchy that prioritizes a subset of individual human rights (or the duties of states not to violate them) above other rights and duties. Consequently, no complex doctrine to reconcile interregime conflicts is necessary, at least with respect to this core set of human rights and any other regime. ${ }^{221}$ Nonetheless, the determination of the existence of a conflict may require the development of new

219. In the same vein, Article 14 of the Draft Articles on the Responsibility of International Organizations establishes that:

An international organization which aids or assists a State or another international organization in the commission of an internationally wrongful act by the State or the latter organization is internationally responsible for doing so if:

(a) the former organization does so with knowledge of the circumstances of the internationally wrongful act; and

(b) the act would be internationally wrongful if committed by that organization.

Responsibility of International Organizations, supra, note 96, art. 14. Article 6 provides that the conduct of any organ or agency of the organization is attributable to the organization. Id.

220. See Buchanan, supra note 99 , at 96 (suggesting that the international order cannot rely on universal rights as part of its conception of its own legitimacy without providing a "credible public justification for the claim that it has properly identified and specified a set of genuinely universal rights").

221. Jeffrey Dunoff aptly characterizes these as regime conflicts. Jeffrey L. Dunoff, International Law in Perplexing Times, 25 MD. J. INT'L L. 11, 21 (2010); see also Dinah Shelton, Normative Hierarchy in International Law, 100 AM. J. INT'L L. 291, 293 (2006) (discussing the need to further develop choice of law principles to address conflicts between norms of equivalent status). Some have looked to Article 31 (3)(c) of the Vienna Convention on the Law of Treaties, distinctions between lex specialis and lex posterior, and the concept of jus cogens in response to the challenge of interregime conflicts. Fragmentation of International Law, supra note 133, ๆ 3; PROST, supra note 97, at 11-12. 
interpretive tools. ${ }^{222}$

\section{Achieving Normative Goals}

A second substantive condition of legitimacy for international courts is that they must promote the purposes of the normative regimes they are charged with interpreting and applying. As discussed above, international courts no longer exist as mere dispute settlers but are increasingly recognized to espouse particular normative regimes. Simply, as mandated by the Vienna Convention on the Law of Treaties, ${ }^{223}$ a court's rulings must be consistent with the object and purpose of the normative regime or regimes it was created to adjudicate. For example, if a human rights court ceases to protect human rights or fails to uphold states' responsibilities not to violate human rights, it no longer possesses justified authority. A court will not lose all legitimacy if it makes a mistake in judgment or if it fails to promote its mission in one or two cases. Rather, its rulings must accord with the institution's underlying objectives with sufficient frequency to justify its authority. ${ }^{224}$

This requires identification of the constellation of normative regimes that a court should consider (e.g., trade law, environmental law, human rights law, investment law), the object and purposes of each of these, and a prioritization of the regimes most important within a particular dispute resolution system. Guidance may be found in constitutive instruments, relevant treaties, custom and general principles, the court's previous interpretations, and critiques by scholars and others. After discerning what law applies and what its purposes are, it is essential to understand the overriding goals or mission of the court or how it should reconcile conflicting regimes. What hierarchy of norms exists in a particular court? In a recent article on effectiveness and international courts, Yuval Shany proposed that determining the goals of international courts requires identification of mandate providers and analysis of the range and variety of their goals. ${ }^{225}$ Although Shany focused almost exclusively on states and international organizations as mandate providers, one can imagine inclusive, public, transparent, and periodic dialogue involving other stakeholders concerning evolving goals for various international courts.

Legitimacy requires that normative goals be achieved within the framework of justice. ${ }^{226}$ In other words, a court that facilitates the violation of a core set of human rights protections is illegitimate, regardless of whether it achieves other normative goals in the process.

222. See Pavoni, supra note 214 , at $650-51$ (discussing a shift in the interpretation of multilateral environmental agreements to reduce conflicts with WTO rules).

223. Vienna Convention on the Law of Treaties, supra note 200, arts. 31-32.

224. See RAZ, supra note 13, at 47 (explaining that the normal way to justify an institution's authority is not to assume that it will always succeed in behaving ideally, but rather that it will do so often enough to justify its own authority).

225. Shany, supra note 83 , at $240-48$.

226. See supra Part III.B for a discussion of legitimacy and justice. 


\section{CONCLUSION}

Traditional approaches to the legitimacy of international courts are based on outmoded assumptions about the impact and role of international courts. This Article proposes a new theory of legitimacy for international courts with both procedural and substantive aspects. First, legal persons whose international legal rights and duties are at issue in international court proceedings must have the right to present their views. Second, to the extent international courts are making law or policy, those potentially affected should have the ability to participate. Third, international courts are legitimate when they help states to better comply with a core set of human rights obligations than states would without international courts. Fourth, international courts cannot facilitate the violation of core norms by states and still retain their legitimacy. Finally, legitimacy requires that courts act in a manner generally consistent with the object and purpose of the normative regimes they interpret and apply.

The articulation of this theory shows that much more work remains to be done. How should we distinguish between international courts' diverse functions? How do we identify the primary normative goals of an international court? Is a diversity of normative hierarchies in different courts a threat to the coherence of international law ${ }^{227}$ This Article takes the position that some basic individual human rights must take precedence over other international legal commitments to other actors. ${ }^{228}$ What guidance needs to be provided to courts deciding between norms of equivalent value to different international legal persons? To what extent does the type of actor to whom the obligation is owed matter? What are the implications for international dispute resolution should the scope of core rights grow over time? How would making the relatively modest institutional changes that this paper suggests affect the effectiveness of international courts?

More work is needed in the field of comparative international courts as well. Which courts are the most and least legitimate? Which ones are farthest behind in crafting institutional reforms to attain procedural fairness and justice and better to achieve normative goals? Which ones are doing the best job? What can courts and court reformers learn from each other's mistakes and successes? If we apply the legitimacy standards presented here, where do the various international courts operating today fall? For example, the ICJ may find itself dangerously far from the top of the list. In the ICJ, no one aside from states has standing in contentious cases or the right to file an amicus brief. Parties to the ICJ Statute do not meet with any frequency to consider amendments.

The court's record with respect to interregime conflicts involving human rights requires more assessment, although in at least two recent cases, it arguably construed immunity doctrines to avoid addressing difficult human rights concerns. ${ }^{229}$ Whether the

227. See PROST, supra note 97 , at $4-7$ (discussing the roots of fragmentation and the "anxiety" it engenders).

228. This Article does not transform all international courts into human rights courts. Rather, all international courts are bound to apply a minimum core set of human rights guarantees agreed to by states, and they cannot facilitate the violation of these core norms. See supra Parts III.B.1-2 for a discussion of the relationship between core human rights and legitimacy.

229. See e.g., Jurisdictional Immunities of the State (Ger. v. It.: Greece Intervening), Judgment, 2012 
court is achieving the normative goals within its purview-and what these goals areis another matter for debate and discussion.

International courts have a significant and growing impact on the rights, duties, and interests of numerous international actors. Their importance and the increasing scope of their authority call for deeper and more creative inquiry about the underpinnings of their legitimacy. This Article employs legal philosophy and jurisprudential approaches to propose that procedural fairness to rights holders and stakeholders and the promotion of relevant normative regimes consistent with fundamental human rights are essential for the legitimacy of international courts. It seeks to motivate stakeholders of all kinds to engage in a serious debate about what justifies the authority of international courts and what limits that authority should have.

I.C.J. 1, I 91 (Feb. 3) (deciding that states enjoy jurisdictional immunity for acta jure imperii causing injury in other states during armed conflict regardless of the gravity of crimes committed or absence of an alternative remedy); Arrest Warrant of 11 April 2000 (Dem. Rep. Congo v. Belg.), Judgment, 2002 I.C.J. 3, ๆ 54 (Feb. 14) (granting an incumbent Minister of Foreign Affairs immunity from criminal jurisdiction outside his home state during his tenure). 
